\title{
WestVirginiaUniversity
}

THE RESEARCH REPOSITORY @ WVU

Graduate Theses, Dissertations, and Problem Reports

2005

\section{Three essays on immigration and outsourcing}

Arsen V. Melkumian

West Virginia University

Follow this and additional works at: https://researchrepository.wvu.edu/etd

\author{
Recommended Citation \\ Melkumian, Arsen V., "Three essays on immigration and outsourcing" (2005). Graduate Theses, \\ Dissertations, and Problem Reports. 4174. \\ https://researchrepository.wvu.edu/etd/4174
}

This Dissertation is protected by copyright and/or related rights. It has been brought to you by the The Research Repository @ WVU with permission from the rights-holder(s). You are free to use this Dissertation in any way that is permitted by the copyright and related rights legislation that applies to your use. For other uses you must obtain permission from the rights-holder(s) directly, unless additional rights are indicated by a Creative Commons license in the record and/ or on the work itself. This Dissertation has been accepted for inclusion in WVU Graduate Theses, Dissertations, and Problem Reports collection by an authorized administrator of The Research Repository @ WVU.

For more information, please contact researchrepository@mail.wvu.edu. 


\title{
Three Essays on Immigration and Outsourcing
}

\author{
Arsen V. Melkumian \\ Dissertation Submitted to the \\ College of Business and Economics \\ at \\ West Virginia University \\ in partial fulfillment of the requirements \\ for the degree of \\ Doctor of Philosophy \\ in \\ Economics
Santiago M. Pinto, Ph.D., Chair
Ronald J. Balvers, Ph.D.
Stratford M. Douglas, Ph.D.
Alexei V. Egorov, Ph.D.
Andrei V. Smirnov, Ph.D.
Department of Economics \\ Morgantown, West Virginia \\ 2005
}

Keywords: chain migration, linewatch hours, border apprehensions

Copyright (C) Arsen V. Melkumian 


\section{Abstract \\ Three essays on \\ Immigration and Outsourcing}

\section{Arsen V. Melkumian}

This dissertation includes essays on legal and illegal immigrations and outsourcing. Chapter 1 introduces the paths that economics has blazed into in the areas of legal and illegal immigration and outsourcing. The first essay, in Chapter 2, presents a Cournot duopoly model of a domestic unionized firm and a foreign firm, where the domestic firm has an option to shift all of its production abroad. An increase in the bargaining power of an employment oriented union will increase domestic output and utility of the union.

The second essay, in Chapter 3, examines illegal immigration in the U.S. from Mexico using annual data on the U.S. border apprehensions of illegal migrants from Mexico and border enforcement. The results support the hypothesis, that recent legal immigrants from Mexico facilitate the flow of illegal migrants from Mexico. This result suggests that large scale amnesties that provide legal status for illegal immigrants should be avoided, as they provide unhealthy stimulus for future illegal immigration. The third essay, in Chapter 4, develops a gravity model of legal immigration using balanced panel data. Higher index of Economic Freedom is found to be associated with increased migration flows. Chapter 5 provides the summary of the dissertation and concluding remarks. 


\section{Acknowledgements}

Now that I have come to completing my degree, I realize it would have been impossible to accomplish it on my own. Many people have helped me along the way.

I wish to express my sincere appreciation and gratitude to my dissertation advisor Santiago Pinto without whom this body of work would have been impossible. Thank you for your continuous support and exceptional guidance. I truly appreciate all of your help.

I am deeply grateful to the members of my dissertation committee: Ronald Balvers, Stratford Douglas, Alexei Egorov and Andrei Smirnov, for all their constructive comments and input in this work.

To Nicki Metts, thank you for always being there when I needed your help. To Saurav Roychoudry and Serhiy Kotsan, thank you for sharing valuable thoughts and information with me and for helping me at any time.

Finally, I would like to express my sincere thanks and appreciation to my wife, Alla Melkumian, for her support and encouragement.

The standard disclaimer applies to any errors or faults found within this dissertation 


\section{Table of Contents}

Notice of Copyright ............................................................

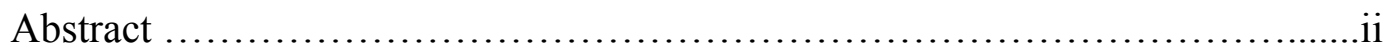

Acknowledgements $\ldots \ldots \ldots \ldots \ldots \ldots \ldots \ldots \ldots \ldots \ldots \ldots \ldots \ldots \ldots \ldots \ldots \ldots \ldots \ldots \ldots$.iii

Table of Contents ..........................................................

List of Tables ...............................................................

List of Figures ....................................................... vii

Chapter 1: Introduction $\quad 1$

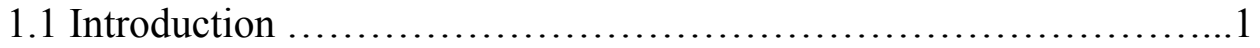

1.2 Models of Unionized Oligopoly ...................................

1.3 Illegal Immigration to the US from Mexico ........................2

1.4 Models of Legal Immigration to the United States ......................

Chapter 2: Unionized Oligopoly and an Option to Outsource 5

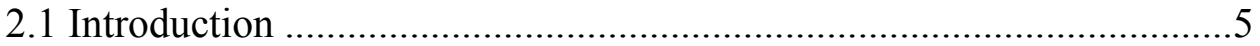

2.2 The Model ............................................................ 7

2.2.1 The Foreign Firm .................................... 10

2.2.2 National Welfare .................................... 10

2.3 Comparative Statics ..............................................

2.4 Summary and Conclusions ......................................

Chapter 3: Illegal Immigration and Recent U.S. Immigration policy 29

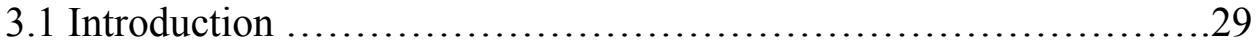

3.2 Theory of Illegal Migration .......................................33

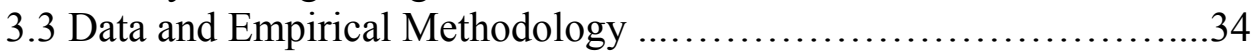

3.4 Empirical Issues and Estimation Results .............................36

3.5 Concluding remarks ........................................... 41

Chapter 4: A Gravity Model of Legal Immigration to the United States 49

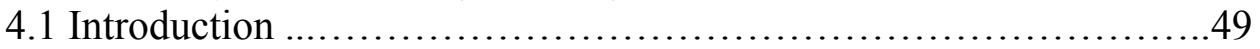

4.2 A Gravity Model of Migration to the United States ...................52

4.2.1 Theoretical Background .................................52

4.2.2 Data and Empirical Methodology ........................55

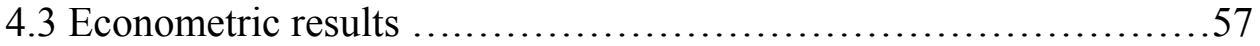

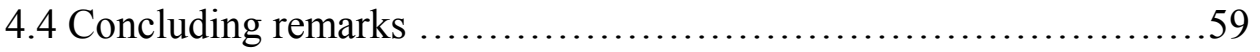




\section{Table of Contents (continued)}

Chapter 5: Summary and Conclusions ....................................64

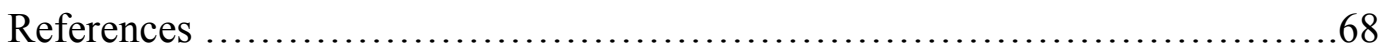




\section{List of Tables}

\section{Tables:}

Table 2.1 Summary of Results .........................................28

Table 3.1 Variable Definitions and Summary Statistics ......................43

Table 3.2 First-Difference Specification of Border Apprehensions with Border Patrol Officers as Measure of Enforcement

Dependent Variable: Border Apprehensions

Table 3.3 First-Difference Specification of Border Apprehensions with Linewatch Hours as Measure of Enforcement ..................45 Dependent Variable: Border Apprehensions

Table 4.1 List of countries included in the migration flow analysis .............61

Table 4.2 Immigration Rate Regressions-Model I ..........................62

Dependent variable: Immigrants admitted by country of birth

Table 4.3 Source Area Compositions of US Immigration, 1996-2000 ..........63 


\section{List of Figures}

\section{Figures:}

Figure 3.1 Enforcement of the U.S. Border, 1968-1998 ............................46

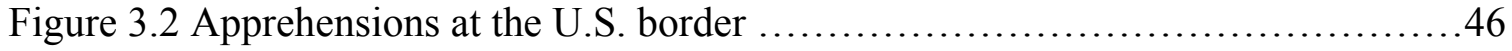

Figure 3.3 Legal Immigrants from Mexico $\ldots \ldots \ldots \ldots \ldots \ldots \ldots \ldots \ldots \ldots \ldots \ldots \ldots \ldots . . \ldots 7$

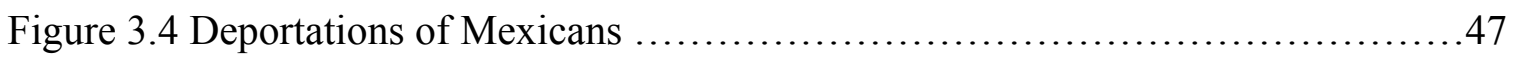

Figure 3.5 Mexican Quota Immigrants Admitted $\ldots \ldots \ldots \ldots \ldots \ldots \ldots \ldots \ldots \ldots \ldots \ldots \ldots . .48$ 


\section{Chapter 1}

\section{Introduction}

\subsection{Introduction}

This dissertation looks at legal and illegal immigration and outsourcing; topics that from time to time attracted attention of economists over the past few decades. The respective literatures are comparatively small and there are still a lot of areas that need to be explored. In addition, research in these areas may lead to adoption of policies that reduce illegal immigration and outsourcing and improve the quality of legal migrants to the United States. In order to acquaint the reader to the subjects, I will provide a brief introduction to each of the topics.

\subsection{Models of Unionized Oligopoly}

The interaction between labor unions and international competition has received a lot of attention. The two popular static models of union behavior used in the literature are the "efficient bargaining" and "right to manage" models. In the "efficient bargaining" model, the domestic firm and the union jointly bargain over wage and employment level, leading to an outcome that lies on the "efficient contract curve". In the right to manage model the domestic firm and the union bargain over wage only and then employment level is chosen by the firm. Even though direct negotiations over employment level are rare, indirect bargaining over employment is quite common ${ }^{1}$, which makes the "efficient bargaining" model more relevant for the analysis.

\footnotetext{
${ }^{1}$ See Bandyopadhyay and Bandyopadhyay (2000) for examples of indirect bargaining over employment level.
} 
In the US some oligopolistic industries, such as automobiles and aircraft manufacturing, are unionized. Mezetti and Dinopoulus (1991) used the "efficient bargaining" model in context of import competition to analyze the bargaining process between a union and a domestic firm, when the latter has an option to switch all of its production abroad. Since then, several others have used the "efficient bargaining" model to study unionized labor markets.

\subsection{Illegal Immigration to the US from Mexico}

With persistently high levels of unemployment of Mexican agricultural and unskilled workers, illegal emigration to the U.S. appears to be a very attractive option for many of Mexico's unemployed residents. In the U.S., the average illegal worker earns about ten to twelve times more per day than the same worker in Mexico. For decades, Mexican illegal migrants have been a major resource of labor for American employers.

The Immigration Reform and Control Act of 1986 made it unlawful for any person knowingly to hire, recruit or refer for a fee any alien not authorized to work, called for an increase in border enforcement budget and provided a legal status to those illegal migrants who could prove continuous residence since 1982. Since 1986, the INS has spent most of its enforcement budget on militarizing and building up the border and has done little to enforce sanctions against those who hire and aid illegal immigrants. For example, there were only twenty-four convictions and fifteen prosecutions for illegal hiring practices in all of 1997.

Current U.S immigration policy is based on the idea that border enforcement reduces attempts to entry by demonstrating that that the cost of illegal entry is too high to 
be worthwhile. However, it appears that border enforcement alone is too costly as a means of controlling illegal border crossing and other programs should be in place to deter illegal immigration.

A guest worker program proposed by the Bush administration in January of 2004, if implemented properly, may provide a prudent solution to the problem. Under this program, illegal migrants already in the US would have to pay an unspecified fee and prove they are employed to obtain a "guest worker" card. A "guest worker" status will allow them to stay in the USA for three years. The legal status granted by this program will last three years and will be renewable once. Participants who do not remain employed and do not follow the rules of the program would not be eligible for continued participation and will be required to return to their home.

\subsection{Models of Legal Immigration to the United States.}

Immigration to the United States has changed from predominance of high-wage counties of origin in the 1950s and 1960s to low-wage countries of origin in the 1970s and 1980s. Until the 1960, immigrants from Europe had a preferential treatment under existing national origin quotas. The national origin quotas were based on 1921 immigrant stock and favored Europeans, especially those from Western Europe.

Immigration Act of 1965 abolished national origin quotas and established a new system that strongly favored family reunification and allowed professional workers into the country regardless their ethnicity and national origin. It was believed by some that the majority of immigrants would still come from "traditional" sources. However, between 1960s and 1990s the proportion of immigrants from Europe fell from over two-thirds to 
less than 12 percent. In the meantime, immigration from Mexico alone rose from 12 to 21 percent. These changes in composition of immigration prompted a reevaluation of factors affecting migration flows to the United States.

Several models have come to prominence to analyze economic, demographic and political factors that affect migration flows. However, most migration studies that I am aware of do not include important countries, such as Nigeria in Africa; Vietnam, Iraq and Lebanon in Asia; Cuba and Haiti in the Caribbean. In addition, despite the undeniable importance of "chain migration" effects-such as stock of foreign-born in the destination country- proxies for these effects are often not included in the analysis. 


\section{Chapter 2}

\section{Unionized Oligopoly and an Option to Outsource}

\subsection{Introduction}

The interaction between labor unions and international competition has received a lot of attention. Brander and Spencer (1988) analyze the effects of unionization in a NashCournot duopoly market. They use the 'right to manage' model, where the firm and union bargain over the wage first and then the firm sets its output level unilaterally. Mezzetti and Dinopoulos (1991) develop a Cournot duopoly model of a domestic unionized firm and a foreign firm. Mezzetti and Dinopoulos (1991) use the 'efficient bargaining' model, where the firm and the union jointly bargain over wage and employment level. Bandyopadhyay and Bandyopadhyay (2000) present a welfare analysis in the 'efficient bargaining' and 'right to manage' model and compare the results.

In recent years, an increasing number of companies in unionized oligopolistic industries, such as automobile and aircraft manufacturing, has shifted production abroad in an effort to cut labor costs. However, the issue of outsourcing in the context of unionized duopoly has received very little attention. Mezzetti and Dinopoulos (1991) modeled the option to outsource and obtained limited results. They developed a model in which a unionized firm competes with a foreign firm for sales in the domestic market. A two-stage game is played by the home country government, the union and two firms. In the first stage, the government announces a tariff imposed on the output of the foreign firm. In the second stage, the domestic firm and union jointly bargain over wage and employment level. They find that a credible threat to shift production abroad increases domestic profits and lowers the negotiated wage. Mezzetti and Dinopoulos (1991) 
abstracted from modeling unionized labor markets in exporting industries. I am not aware of any papers modeling option to outsource in context of unionized labor markets in exporting industries and present a model, which intends to fill the gap. I use the model to inquire into the effects of union bargaining power, foreign wage, foreign and domestic subsidy and the wage in the outsourcing country.

The model considers a Stone-Geary representation that has been used extensively in the literature (e.g. Dertouzos and Pencavel, 1981, Pencavel, 1984, MaCurdy and Pencavel, 1986, Mezzetti and Dinopoulos, 1991, Bandyopadhyay and Bandyopadhyay, 2000).

I find that if the union is employment oriented, then an increase in its bargaining power increases domestic output and union's utility level and has an ambiguous effect on domestic profits. This result is similar to that of Mezetti and Dinopoulos (1991). I also find that if the union is employment oriented, then an increase in its bargaining power may reduce domestic welfare, a result distinct to that of Mezetti and Dinopoulos (1991) and Brander and Spencer $(1988)^{2}$.

I find that if the domestic firm can credibly threaten to shift all of its production abroad, then an increase in the outsourcing country's wage may decrease a union's utility and decrease domestic welfare if the union is labor oriented. In addition, this paper shows that if the inverse demand function is convex, then an increase in the foreign wage increases utility of a wage neutral union.

Section 2.2 outlines the model. Section 2.3 presents comparative statics analysis. Section 2.4 presents summary and conclusion.

\footnotetext{
${ }^{2}$ Mezetti and Dinopoulus (1991) and Brander and Spencer (1988) find that if the union is employment oriented, then an increase in its bargaining power increases domestic welfare.
} 


\subsection{The Model}

In this model two strictly exporting firms (domestic and foreign) are engaged in a duopolistic competition in a homogeneous good in a third nation's market. The domestic firm is unionized and produces all of its output at the domestic plant, however the domestic firm has an option to close the domestic plant and produce all of its output abroad in the fourth country. The domestic firm's local plant conducts an efficient Nash bargain with its union while the foreign firm faces a competitive market. The equilibrium is determined in a one-stage non-cooperative game. In the first stage of the game, the domestic union and the domestic firm negotiate an efficient contract and each firm chooses its output in a Nash-Cournot fashion. We assume that the production functions are:

$$
q=L, q^{*}=L^{*}
$$

where $(w, q, L)$ and $\left(w^{*}, q^{*}, L^{*}\right)$ are the wage, output and labor combinations of the domestic and foreign firm correspondingly.

Let us assume that the inverse demand function for the export good is:

$$
P=P(Q)=P\left(L+L^{*}\right), P^{\prime}<0
$$

The union's preferences are represented by the following modified Stone-Geary utility function:

$$
\mathrm{U}=(\mathrm{w}-\mathrm{b})^{\beta} \mathrm{L} \text {, where } \beta>0 \text {, }
$$

where $U$ is the utility of the domestic union, $w$ and $L$ are the wage rate and the employment level negotiated between the domestic union and the domestic firm, $b$ is the alternative (competitive) wage and $\beta$ is the degree of wage orientation of the domestic union. The union is wage oriented if $\beta>1$, wage neutral if $\beta=1$ and employment 
oriented if $\beta<1$. Pencavel (1984) shows that there indeed is empirical evidence that unions differ according to the degree of their wage orientation.

The subsidy inclusive domestic firm's profit is:

$$
\Pi=\left[\mathrm{P}\left(\mathrm{L}+\mathrm{L}^{*}\right)-\mathrm{w}+\mathrm{s}\right] \mathrm{L},
$$

where $w$ is the negotiated domestic wage and $s$ is the domestic firm's subsidy level.

The subsidy inclusive foreign firm's profit is:

$$
\Pi^{*}=\left[\mathrm{P}\left(\mathrm{L}+\mathrm{L}^{*}\right)-\mathrm{w}^{*}+\mathrm{s}^{*}\right] \mathrm{L}^{*},
$$

where $w^{*}$ is the competitive foreign wage and $s^{*}$ is the foreign firm's subsidy level.

The domestic firm's local plant and the union conduct an efficient Nash bargain to jointly determine $\mathrm{w}$ and L. However, if no agreement is reached between the union and domestic firm, the domestic firm can produce abroad in the fourth country and pay workers the competitive wage $\xi$ that prevails in the country. Thus, the reservation profit of the firm is:

$$
\psi=(P-\xi) \hat{L}
$$

where $\hat{L}$ is the Cournot output level of production of the domestic firm when its production facilities are located abroad and $P\left(\hat{L}+\hat{L}^{*}\right)$ is the home country price. The reservation profit $\psi=P \hat{L}-\xi \hat{L}$ must be less than domestic profit $\Pi=\left[\mathrm{P}\left(\mathrm{L}+\mathrm{L}^{*}\right)-\mathrm{w}+\mathrm{s}\right] \mathrm{L}$, otherwise the domestic firm will produce abroad.

We assume here that $w-s<w^{*}$, otherwise the home country will switch its production 
$\operatorname{abroad}^{3}$.

Let $\pi=\Pi-\psi$. Hence, following Mezzetti and Dinoupolos (1991) the generalized Nash bargaining problem is:

$$
\operatorname{Max}_{\mathrm{w}, \mathrm{L}}\left\{\mathrm{U}^{\alpha} \pi^{1-\alpha}\right\}=\operatorname{Max}_{\mathrm{w}, \mathrm{L}}\left\{\left[(\mathrm{W}-\mathrm{b})^{\beta} \mathrm{L}\right]^{\alpha} \cdot \pi^{1-\alpha}\right\}, \quad 0<\alpha<1,
$$

where $\alpha$ is the relative bargaining power of the union.

The first order conditions with respect to $\mathrm{w}$ and $\mathrm{L}$ are:

$$
\begin{aligned}
& \alpha \pi U_{w}+(1-\alpha) U \pi_{w}=0, \\
& \alpha \pi U_{L}+(1-\alpha) U \pi_{L}=0 .
\end{aligned}
$$

It follows directly from the first order conditions that:

$$
\begin{aligned}
& \alpha \pi U_{w}+(1-\alpha) U \pi_{w}=0, \\
& \alpha \pi=(\alpha-1) L \pi_{L} .
\end{aligned}
$$

Equation (10) represents Nash Bargaining Curve (see Mezzetti and Dinopoulos, 1991). Dividing equation (7) by (8) we obtain:

$$
\frac{U_{w}}{U_{L}}=\frac{\pi_{w}}{\pi_{L}}
$$

Equation (11) implicitly defines $w$ as a function of L, given $L^{*}, s$ and $s^{*}$. Equation (11) defines an Efficient Contract. The Nash Bargaining Curve (equation (10)) together with the Efficient Contract (equation (11)) determines the Nash Bargaining Equilibrium.

Using equations (3), (4), (5) and (11) we can obtain the following representation of the Efficient Contract:

\footnotetext{
${ }^{3}$ In other words, I assume that exogenous variables are such that the threat of outsourcing is a threat that is never realized. See Appendix C for additional information.
} 


$$
\frac{w-b}{\beta}=w-P-P^{\prime} L-s .
$$

If the union is wage neutral ( $\beta=1)$ then equation (12) becomes independent of $w$ and the domestic employment level will not depend on the domestic wage rate. Using equations (3), (4), (5) and (10) we can obtain the following representation of the Nash Bargaining Curve:

$$
w=P^{\prime} L+P+s-\alpha P^{\prime} L-\alpha \frac{\psi}{L} .
$$

\subsubsection{The foreign firm}

The non-unionized foreign firm faces a given wage $w^{*}$ and its subsidy inclusive profit is:

$$
\Pi^{*}=\left[\mathrm{P}\left(\mathrm{L}+\mathrm{L}^{*}\right)-\mathrm{w}^{*}+\mathrm{s}^{*}\right] \mathrm{L}^{*}
$$

where $s^{*}$ is the foreign firm's subsidy level. The first order condition of the foreign firm under Cournot-Nash behavior is:

$$
P+L^{*} P^{\prime}=w^{*}-s^{*},
$$

which states that marginal revenue equals the foreign wage $w^{*}$, minus the foreign subsidy $s^{*}$. Equation (15) together with the Nash Bargaining Curve (equation(13)) and Efficient Contract (equation(12)) constitute a system of three equations in three unknowns whose solution is the equilibrium outcome of the model. Mezetti and Dinopoulos (1991) show that a unique equilibrium exists in such a model.

\subsubsection{National Welfare}


Let $\mathrm{N}$ be the total domestic workforce. Domestic workers that cannot find employment in the firm are absorbed by the competitive non-unionized sector and paid competitive wage $\mathrm{b}<\mathrm{w}$. Then the number of workers employed by the competitive sector equals (N-L). Let the competitive sector produce the numeraire good with the following technology:

$$
\mathrm{X}=\mathrm{b}(\mathrm{N}-\mathrm{L}) \text {. }
$$

Now, let us consider a utilitarian representation of domestic welfare where we add the profit, wage incomes and the tax burden throughout the economy:

$$
\mathrm{W}=(\mathrm{P}-\mathrm{w}+\mathrm{s}) \mathrm{L}+\mathrm{wL}+\mathrm{b}(\mathrm{N}-\mathrm{L})-\mathrm{sL}=\mathrm{PL}+\mathrm{c}(\mathrm{N}-\mathrm{L})=(\mathrm{P}-\mathrm{b}) \mathrm{L}+\mathrm{bN} .
$$

Such a welfare function is common to this literature (see Brander and Spencer, 1988 and Bandyopadhyay and Bandyopadhyay, 2001).

National Welfare in the foreign country (where every worker receives competitive wage $\mathrm{w}^{*}$ ) has a similar structure and is given by:

$$
\mathrm{W}^{*}=\left(\mathrm{P}-\mathrm{w}^{*}+\mathrm{s}^{*}\right) \mathrm{L}^{*}+\mathrm{w}^{*} \mathrm{~N}^{*}-\mathrm{s}^{*} \mathrm{~L}^{*}=\left(\mathrm{P}-\mathrm{w}^{*}\right) \mathrm{L}^{*}+\mathrm{w}^{*} \mathrm{~N}^{*} .
$$

\subsection{Comparative Statics}

In this section I examine the comparative statics effects of union relative bargaining power, domestic and foreign subsidies and foreign wage rate. Following Brander and Spencer (1985) and I assume that the domestic firm's marginal revenue declines in the

foreign output level and the foreign firm's marginal revenue declines in the domestic output level. In other words:

$$
P^{\prime}+L P^{\prime \prime}<0 \text {, and } P^{\prime}+L^{*} P^{\prime \prime}<0
$$


Equations (12), (13) and (15) determine the three endogenous variables of the model.

Totally differentiating equations (12), (13) and (15) we can calculate the changes in $L, L^{*}$ and $w$ with respect to small changes in $\alpha, s, s^{*}$ and $w^{*}$.

$$
\left\{\begin{array}{l}
\left(\frac{1}{\beta}-1\right) d w+\left(2 P^{\prime}+L P^{\prime \prime}\right) d L+\left(P^{\prime}+L P^{\prime \prime}\right) d L^{*}=-d s, \\
(0) d w+\left(P^{\prime}+L^{*} P^{\prime \prime}\right) d L+\left(2 P^{\prime}+L^{*} P^{\prime \prime}\right) d L^{*}=d w^{*}-d s^{*}, \\
(-1) d w+\left(L P^{\prime \prime}+2 P^{\prime}-\alpha L P^{\prime \prime}-\alpha P^{\prime}+\psi \alpha \frac{1}{L^{2}}\right) d L+\left(P^{\prime}+P^{\prime \prime} L-\alpha L P^{\prime \prime}\right) d L^{*}= \\
=\left(P^{\prime} L+\frac{\psi}{L}\right) d \alpha-d s .
\end{array}\right.
$$

Setting $d s=d s^{*}=d w^{*}=0$, and expressing system (19) in matrix form we obtain:

$$
\left(\begin{array}{ccc}
\left(\frac{1}{\beta}-1\right) & \left(2 P^{\prime}+L P^{\prime \prime}\right) & \left(P^{\prime}+L P^{\prime \prime}\right) \\
0 & \left(P^{\prime}+L^{*} P^{\prime \prime}\right) & \left(2 P^{\prime}+L^{*} P^{\prime \prime}\right) \\
-1 & \left(L P^{\prime \prime}+2 P^{\prime}-\alpha L P^{\prime \prime}-\alpha P^{\prime}+\psi \alpha \frac{1}{L^{2}}\right) & \left(P^{\prime}+P^{\prime \prime} L-\alpha L P^{\prime \prime}\right)
\end{array}\right)\left(\begin{array}{l}
\frac{d w}{d \alpha} \\
\frac{d L}{d \alpha} \\
\frac{d L^{*}}{d \alpha}
\end{array}\right)=\left(\begin{array}{l}
0 \\
0 \\
P^{\prime} L+\frac{\psi}{L}
\end{array}\right) .
$$

Now, let us assume that:

$$
(1-\alpha) P^{\prime}+\frac{\psi}{L^{2}}<0
$$

and consider two cases.

Case 1. The union is wage neutral $(\beta=1)$. Let $\mathrm{A}$ be the coefficient matrix. Then,

$$
|A|=(-1)\left[\left(2 P^{\prime}+L P^{\prime \prime}\right)\left(2 P^{\prime}+L^{*} P^{\prime \prime}\right)-\left(P^{\prime}+L P^{\prime \prime}\right)\left(P^{\prime}+L^{*} P^{\prime \prime}\right)\right]
$$

Since by $(18 \mathrm{a})$ we have that $\left(P^{\prime}+L P^{\prime \prime}\right)<0$ and $\left(P^{\prime}+L^{*} P^{\prime \prime}\right)<0$, then it is seen 
readily that $|A|<0$, and matrix A is nonsingular. Using Cramer's rule we determine that:

$$
\begin{aligned}
& \frac{d w}{d \alpha}=-\left(P^{\prime} L+\frac{\psi}{L}\right), \\
& \frac{d L}{d \alpha}=0, \text { and } \frac{d L^{*}}{d \alpha}=0 .
\end{aligned}
$$

It follows from equation (20a) that $\left(P^{\prime} L+\frac{\psi}{L}\right)<0$, which in turn implies that $\frac{d w}{d \alpha}>0$. In other words, we have that increase in relative bargaining power of the union increases the wage rate of the domestic workers if the union is wage neutral.

Totally differentiating the union's utility function and considering that the union is wage neutral $(\beta=1)$, we obtain:

$$
\frac{d U}{d \alpha}=L \frac{d w}{d \alpha}+(w-b) \frac{d L}{d \alpha}
$$

Since $\frac{d w}{d \alpha}>0$ and $\frac{d L}{d \alpha}=0$, it follows that an increase in the relative bargaining power of the union increases utility of a wage neutral union. Incidentally, it follows readily from equation (4) that domestic firm's profit decreases as the relative bargaining power of the wage neutral union increases. Indeed, only domestic wage $w$ changes (increases) in equation (4) with the increase in $\alpha$. Also, since neither domestic nor foreign welfare depend on the domestic wage, they are unaffected by the increase in $\alpha$.

Case 2. The union is employment oriented. $(0<\beta<1)$.

If the union is employment oriented, then $\left(\frac{1}{\beta}-1\right)>0$. It follows from equation (20a) that: 


$$
\left(P^{\prime}-\alpha\left(P^{\prime}-\frac{\psi}{L^{2}}\right)\right)<0
$$

Let $\theta$ be defined as follows:

$$
\begin{aligned}
& \theta=\left(\left(P^{\prime}+L^{*} P^{\prime \prime}\right)\left(P^{\prime}+P^{\prime \prime} L-\alpha L P^{\prime \prime}\right)-\left(2 P^{\prime}+L^{*} P^{\prime \prime}\right)\left(L P^{\prime \prime}+2 P^{\prime}-\alpha L P^{\prime \prime}-\alpha P^{\prime}+\psi \alpha \frac{1}{L^{2}}\right)\right)= \\
& \left(\left(P^{\prime}+L^{*} P^{\prime \prime}\right)\left(P^{\prime}+L P^{\prime \prime}-\alpha L P^{\prime \prime}\right)-\left(2 P^{\prime}+L^{*} P^{\prime \prime}\right)\left(\left(P^{\prime}+L P^{\prime \prime}-\alpha L P^{\prime \prime}\right)+\left(P^{\prime}-\alpha\left(P^{\prime}-\frac{\psi}{L^{2}}\right)\right)\right)\right)
\end{aligned}
$$

Here we observe, that:

$$
\begin{aligned}
& \left(P^{\prime}+L^{*} P^{\prime \prime}\right)<\left(2 P^{\prime}+L^{*} P^{\prime \prime}\right), \text { and } \\
& \left(P^{\prime}+L P^{\prime \prime}-\alpha L P^{\prime \prime}\right)<\left(\left(P^{\prime}+L P^{\prime \prime}-\alpha L P^{\prime \prime}\right)+\left(P^{\prime}-\alpha\left(P^{\prime}-\frac{\psi}{L^{2}}\right)\right)\right.
\end{aligned}
$$

which implies that $\theta<0^{4}$. Let $\left|A_{1}\right|$ be the coefficient matrix. Then,

$$
\left|A_{1}\right|=|A|+\left(\frac{1}{\beta}-1\right) \theta \text {, where }|A| \text { is as defined in case } 1 \text {. }
$$

Then, it is seen readily that $\left|A_{1}\right|<0$, and

$$
\frac{d w}{d \alpha}=\left(P^{\prime} L+\frac{\psi}{L}\right) \frac{\left[\left(2 P^{\prime}+L P^{\prime \prime}\right)\left(2 P^{\prime}+L^{*} P^{\prime \prime}\right)-\left(P^{\prime}+L P^{\prime \prime}\right)\left(P^{\prime}+L^{*} P^{\prime \prime}\right)\right]}{\left|A_{1}\right|}>0
$$

$$
\begin{gathered}
\frac{d L}{d \alpha}=\left\{\left[-\left(\frac{1}{\beta}-1\right)\left(2 P^{\prime}+L^{*} P^{\prime \prime}\right)\left(P^{\prime} L+\frac{\psi}{L}\right)\right] /\left|A_{1}\right|\right\}>0, \\
\frac{d L^{*}}{d \alpha}=\left\{\left[\left(\frac{1}{\beta}-1\right)\left(P^{\prime}+L^{*} P^{\prime \prime}\right)\left(P^{\prime} L+\frac{\psi}{L}\right)\right] /\left|A_{1}\right|\right\}<0 .
\end{gathered}
$$

\footnotetext{
${ }^{4}$ Note, that all four terms that $\theta$ consists of are negative.
} 


$$
\frac{d\left(L+L^{*}\right)}{d \alpha}=\left\{\left[\left(-P^{\prime}\right)\left(\frac{1}{\beta}-1\right)\left(P^{\prime} L+\frac{\psi}{L}\right)\right] /\left|A_{1}\right|\right\}>0,
$$

We see that if the union is employment oriented, then an increase in the bargaining power will increase domestic output utility of the union and will have an ambiguous effect on domestic profits and welfare. This result is similar to those of Mezetti and Dinopoulus (1991) and Bandyopadhyay and Bandyopadhyay (2000).

The following proposition summarizes the most interesting results above.

Proposition 1. If the union is wage neutral, then an increase in its relative bargaining power:

(i) increases domestic wage;

(ii) does not affect domestic and foreign employment(output) level and welfare;

(iii) increases the union's utility level and decreases the domestic firm's profit level.

Now, assuming that domestic Union is wage neutral $(\beta=1)$, setting $d s=d s^{*}=d \alpha=0$, and expressing system (19) in matrix form we obtain:

$$
\left(\begin{array}{ccc}
0 & \left(2 P^{\prime}+L P^{\prime \prime}\right) & \left(P^{\prime}+L P^{\prime \prime}\right) \\
0 & \left(P^{\prime}+L^{*} P^{\prime \prime}\right) & \left(2 P^{\prime}+L^{*} P^{\prime \prime}\right) \\
-1 & \left(L P^{\prime \prime}+2 P^{\prime}-\alpha L P^{\prime \prime}-\alpha P^{\prime}+\psi \alpha \frac{1}{L^{2}}\right) & \left(P^{\prime}+P^{\prime \prime} L-\alpha L P^{\prime \prime}\right)
\end{array}\right)\left(\begin{array}{c}
\frac{d w}{d w^{*}} \\
\frac{d L}{d w^{*}} \\
\frac{d L^{*}}{d w^{*}}
\end{array}\right)=\left(\begin{array}{l}
0 \\
1 \\
0
\end{array}\right) .
$$

It follows from (25) that: 
$\frac{d L}{d w^{*}}=\frac{\left(P^{\prime}+L P^{\prime \prime}\right)}{|A|}>0, \frac{d L^{*}}{d w^{*}}=-\frac{\left(2 P^{\prime}+L P^{\prime \prime}\right)}{|A|}<0$, and $\frac{d\left(L+L^{*}\right)}{d w^{*}}=-\frac{P^{\prime}}{|A|}<0$.

Totally differentiating the domestic firm' welfare function (equation (17)) we obtain:

$$
\frac{d W}{d w^{*}}=\left[L P^{\prime} \frac{d\left(L+L^{*}\right)}{d w^{*}}+P \frac{d L}{d w^{*}}\right]>0
$$

It follows from system (25) that

$$
\begin{aligned}
& \operatorname{Sign}\left(\frac{d w}{d w^{*}}\right)= \\
& \operatorname{Sign}\left(\left[\left(2 P^{\prime}+L P^{\prime \prime}\right)\left(P^{\prime}+P^{\prime \prime} L-\alpha L P^{\prime \prime}\right)-\left(P^{\prime}+L P^{\prime \prime}\right)\left(2 P^{\prime}+L P^{\prime \prime}-\alpha\left(P^{\prime}+L P^{\prime \prime}\right)+\psi \alpha \frac{1}{L^{2}}\right)\right]\right)= \\
& \operatorname{Sign}\left(\left[P^{\prime}\left(P^{\prime}+P^{\prime \prime} L-\alpha L P^{\prime \prime}\right)\right]-\left(P^{\prime}+L P^{\prime \prime}\right)\left((1-\alpha) P^{\prime}+\psi \alpha \frac{1}{L^{2}}\right)\right) .
\end{aligned}
$$

Assuming that the inverse demand function is convex $\left(P^{\prime \prime}>0\right)$ we have that

$$
P^{\prime}<\left((1-\alpha) P^{\prime}+\psi \alpha \frac{1}{L^{2}}\right) \text { and }\left(P^{\prime}+P^{\prime \prime} L-\alpha L P^{\prime \prime}\right)<\left(P^{\prime}+L P^{\prime \prime}\right)
$$

Observing that all four terms in (27b) are negative, we have:

$\left(\frac{d w}{d w^{*}}\right)>0$

The following proposition summarizes the results of our analysis.

Proposition 2. If the union is wage neutral, then an increase in foreign wage:

(i) increases domestic employment (output) level and decreases foreign employment (output) level;

(ii) increases domestic welfare and has indeterminate effects on foreign 
welfare and domestic profits and union's utility.

(iii) Increases union's utility if the inverse demand function is convex.

(iv) Increases domestic profits and union's utility regardless of union's wage orientation and the shape of the inverse demand function if the union has almost no bargaining power.

(v) Increases domestic profits if the union has almost all the bargaining power.

Also, it is shown in Appendix B that if the union is employment oriented and has almost all the bargaining power then an increase in foreign wage has indeterminate effects on the union's utility.

Now, assuming that domestic Union is wage neutral $(\beta=1)$, setting $d s=d w^{*}=d \alpha=0$, and expressing system (19) in matrix form we obtain:

$$
\left(\begin{array}{ccc}
0 & \left(2 P^{\prime}+L P^{\prime \prime}\right) & \left(P^{\prime}+L P^{\prime \prime}\right) \\
0 & \left(P^{\prime}+L^{*} P^{\prime \prime}\right) & \left(2 P^{\prime}+L^{*} P^{\prime \prime}\right) \\
-1 & \left(L P^{\prime \prime}+2 P^{\prime}-\alpha L P^{\prime \prime}-\alpha P^{\prime}+\psi \alpha \frac{1}{L^{2}}\right) & \left(P^{\prime}+P^{\prime \prime} L-\alpha L P^{\prime \prime}\right)
\end{array}\right)\left(\begin{array}{l}
\frac{d w}{d s^{*}} \\
\frac{d L}{d s^{*}} \\
\frac{d L^{*}}{d s^{*}}
\end{array}\right)=\left(\begin{array}{l}
0 \\
-1 \\
0
\end{array}\right) .
$$

It follows from (28) that:

$$
\begin{aligned}
& \frac{d L}{d s^{*}}=-\frac{\left(P^{\prime}+L P^{\prime \prime}\right)}{|A|}<0, \quad \frac{d L^{*}}{d s^{*}}=\frac{\left(2 P^{\prime}+L P^{\prime \prime}\right)}{|A|}>0, \text { and } \frac{d\left(L+L^{*}\right)}{d s^{*}}=\frac{P^{\prime}}{|A|}>0 . \\
& \frac{d W}{d s^{*}}=\left[L P^{\prime} \frac{d\left(L+L^{*}\right)}{d s^{*}}+P \frac{d L}{d s^{*}}\right]<0 .
\end{aligned}
$$


The following proposition summarizes the above results.

Proposition 3. If the union is wage neutral, then an increase in foreign subsidy:

(i) decreases domestic welfare and employment (output) level and increases foreign employment (output) level;

(ii) decreases domestic profits regardless of union's wage orientation if the union has almost no bargaining power.

It follows from Appendix B that if the union is employment oriented and has almost all the bargaining power then an increase in foreign subsidy also decreases domestic employment level and increases foreign employment level. From Appendix A we see that if the union has almost no bargaining power then regardless of its wage orientation an increase in foreign subsidy decreases domestic employment and increases foreign employment.

Mezzetti and Dinopoulos (1991) abstracted from modeling unionized duopolists in exporting industries, however they conjectured that increase in export subsidy will increase employment level and therefore will be welcomed by labor unions. We see from the proposition above that an increase in foreign export subsidy does increase foreign employment level in the case of a wage neutral union.

Next, assuming that domestic Union is wage neutral $(\beta=1)$, setting $d s^{*}=d w^{*}=d \alpha=0$, and expressing system (19) in matrix form we obtain:

$$
\left(\begin{array}{ccc}
0 & \left(2 P^{\prime}+L P^{\prime \prime}\right) & \left(P^{\prime}+L P^{\prime \prime}\right) \\
0 & \left(P^{\prime}+L^{*} P^{\prime \prime}\right) & \left(2 P^{\prime}+L^{*} P^{\prime \prime}\right) \\
-1 & \left(L P^{\prime \prime}+2 P^{\prime}-\alpha L P^{\prime \prime}-\alpha P^{\prime}+\psi \alpha \frac{1}{L^{2}}\right) & \left(P^{\prime}+P^{\prime \prime} L-\alpha L P^{\prime \prime}\right)
\end{array}\right)\left(\begin{array}{l}
\frac{d w}{d s} \\
\frac{d L}{d s} \\
\frac{d L^{*}}{d s}
\end{array}\right)=\left(\begin{array}{l}
-1 \\
0 \\
-1
\end{array}\right) .
$$


It follows from (31) that:

$$
\begin{aligned}
& \frac{d L}{d s}=\frac{\left(2 P^{\prime}+L^{*} P^{\prime \prime}\right)}{|A|}>0, \frac{d L^{*}}{d s}=-\frac{\left(P^{\prime}+L^{*} P^{\prime \prime}\right)}{|A|}<0, \text { and } \frac{d\left(L+L^{*}\right)}{d s}=\frac{P^{\prime}}{|A|}>0 . \\
& \frac{d W}{d s}=\left[L P^{\prime} \frac{d\left(L+L^{*}\right)}{d s}+P \frac{d L}{d s}\right]
\end{aligned}
$$

We see that an increase in domestic export subsidy does increase the domestic employment (output) level; however it has an ambiguous effect on domestic welfare (since the two terms of $\frac{d W}{d s}$ have an opposite sign). Let us summarize the results in the following proposition.

Proposition 4. If the union is wage neutral, then an increase in domestic subsidy:

(i) increases domestic employment (output) level; decreases foreign employment (output) level;

(ii) has an ambiguous effect on domestic welfare and decreases foreign welfare.

(iii) increases union's utility regardless of union's wage orientation if the union has almost no bargaining power.

Next, totally differentiating equations (12), (13) and (15) and expressing system (19) in matrix form we obtain: 


$$
\left(\begin{array}{ccc}
\left(\frac{1}{\beta}-1\right) & \left(2 P^{\prime}+L P^{\prime \prime}\right) & \left(P^{\prime}+L P^{\prime \prime}\right) \\
0 & \left(P^{\prime}+L^{*} P^{\prime \prime}\right) & \left(2 P^{\prime}+L^{*} P^{\prime \prime}\right) \\
-1 & \left(L P^{\prime \prime}+2 P^{\prime}-\alpha L P^{\prime \prime}-\alpha P^{\prime}+\psi \alpha \frac{1}{L^{2}}\right) & \left(P^{\prime}+P^{\prime \prime} L-\alpha L P^{\prime \prime}\right)
\end{array}\right)\left(\begin{array}{l}
\frac{d w}{d \xi} \\
\frac{d L}{d \xi} \\
\frac{d L^{*}}{d \xi}
\end{array}\right)=\left(\begin{array}{l}
0 \\
0 \\
\frac{\alpha \psi^{\prime}}{L}
\end{array}\right) .
$$

Let $\mathrm{M}$ be the coefficient matrix. We have seen already that given that the union is either wage neutral $(\beta=1)$ or employment oriented $(0<\beta<1)$, the determinant of the coefficient matrix is negative.

It follows from (34) that:

$$
\begin{aligned}
& \frac{d w}{d \xi}=\left[\frac{\alpha \psi^{\prime}}{L}\left[\left(2 P^{\prime}+L P^{\prime \prime}\right)\left(2 P^{\prime}+L^{*} P^{\prime \prime}\right)-\left(P^{\prime}+L P^{\prime \prime}\right)\left(P^{\prime}+L^{*} P^{\prime \prime}\right)\right]\right] /|M|, \\
& \frac{d L}{d \xi}=\left[\left(\frac{1}{\beta}-1\right)\left(-\frac{\alpha \psi^{\prime}}{L}\right)\left[2 P^{\prime}+L^{*} P^{\prime \prime}\right]\right] /|M|, \\
& \frac{d L^{*}}{d \xi}=\left[\left(\frac{1}{\beta}-1\right)\left(\frac{\alpha \psi^{\prime}}{L}\right)\left(P^{\prime}+L^{*} P^{\prime \prime}\right)\right] /|M|, \\
& \frac{d\left(L+L^{*}\right)}{d \xi}=\left[\left(\frac{1}{\beta}-1\right)\left(-\frac{\alpha \psi^{\prime}}{L}\right) P^{\prime}\right] /|M| .
\end{aligned}
$$

Here we observe that $\frac{d w}{d \xi}>0$ for both wage neutral and employment oriented union. Also, $\left(\frac{d L}{d \xi}\right)=\left(\frac{d L^{*}}{d \xi}\right)=0$ if the union is wage neutral. If the union is labor 
oriented we have that $\left(\frac{d L}{d \xi}\right)>0$ and $\left(\frac{d L^{*}}{d \xi}\right)<0$.

Proposition 5. If the domestic firm can credibly threaten to shift production abroad, then an increase in the outsourcing country's wage:

(i) Increases the utility of the union, decreases domestic profits; does not affect domestic and foreign employment and welfare if the union is wage neutral.

(ii) Increases the utility of the union, increases domestic employment and welfare; decreases foreign employment and has an ambiguous effect on domestic profits and foreign welfare if the union is labor oriented.

We see from the proposition above that an increase in the outsourcing country's wage may have unexpected welfare effects if the union is labor oriented $^{5}$.

\subsection{Summary and Conclusions}

In this paper I develop a simple static model of unionization and international competition. I use the model to inquire into the effects of bargaining power, subsidies and the threat to shift production abroad. I find that if the domestic firm is a multinational that can credibly threaten to shift production abroad, then an increase in the outsourcing country's wage may decrease the union's utility and decrease domestic welfare if the union is labor oriented.

My analysis highlights the need to estimate empirically the employment and wage

\footnotetext{
${ }^{5}$ Table A.1 summarizes the results of Section 2.3 .
} 
orientation of union preferences. Also an interesting implication is that an increase in domestic subsidy increases union's utility regardless of its orientation if the union has almost no bargaining power. If the inverse demand function is convex, then an increase in foreign wage increases utility of a wage neutral union. If the union has almost no bargaining power, then an increase in foreign wage increases domestic profits and union's utility regardless of the union's wage orientation and shape of the inverse demand function. If the union is wage neutral, then an increase in domestic subsidy increases union's utility if the union has almost no bargaining power.

Finally, observe that my analysis abstracted from modeling a duopolistic competition between two unionized exporting firms. This presents an interesting avenue for future research. 


\section{Appendix A}

\section{Comparative static effects for a union with almost no bargaining}

\section{power}

If the union has almost no bargaining power $(\alpha \approx 0)$ it follows from system (19) that

$$
\begin{aligned}
& \left(\begin{array}{ccc}
\left(\frac{1}{\beta}-1\right) & \left(2 P^{\prime}+L P^{\prime \prime}\right) & \left(P^{\prime}+L P^{\prime \prime}\right) \\
0 & \left(P^{\prime}+L^{*} P^{\prime \prime}\right) & \left(2 P^{\prime}+L^{*} P^{\prime \prime}\right) \\
-1 & \left(L P^{\prime \prime}+2 P^{\prime}\right) & \left(P^{\prime}+P^{\prime \prime} L\right)
\end{array}\right)\left(\begin{array}{l}
\frac{d w}{d w^{*}} \\
\frac{d L}{d w^{*}} \\
\frac{d L^{*}}{d w^{*}}
\end{array}\right)=\left(\begin{array}{l}
0 \\
1 \\
0
\end{array}\right), \\
& \left(\begin{array}{ccc}
\left(\frac{1}{\beta}-1\right) & \left(2 P^{\prime}+L P^{\prime \prime}\right) & \left(P^{\prime}+L P^{\prime \prime}\right) \\
0 & \left(P^{\prime}+L^{*} P^{\prime \prime}\right) & \left(2 P^{\prime}+L^{*} P^{\prime \prime}\right) \\
-1 & \left(L P^{\prime \prime}+2 P^{\prime}\right) & \left(P^{\prime}+P^{\prime \prime} L\right)
\end{array}\right)\left(\begin{array}{l}
\frac{d w}{d s^{*}} \\
\frac{d L}{d s^{*}} \\
\frac{d L^{*}}{d s^{*}}
\end{array}\right)=\left(\begin{array}{l}
0 \\
-1 \\
0
\end{array}\right), \\
& \left(\begin{array}{ccc}
\frac{1}{\beta}-1 & \left(2 P^{\prime}+L P^{\prime \prime}\right) & \left(P^{\prime}+L P^{\prime \prime}\right) \\
0 & \left(P^{\prime}+L^{*} P^{\prime \prime}\right) & \left(2 P^{\prime}+L^{*} P^{\prime \prime}\right) \\
-1 & \left(L P^{\prime \prime}+2 P^{\prime}\right) & \left(P^{\prime}+P^{\prime \prime} L\right)
\end{array}\right)\left(\begin{array}{l}
\frac{d w}{d s} \\
\frac{d L}{d s} \\
\frac{d L^{*}}{d s}
\end{array}\right)=\left(\begin{array}{l}
-1 \\
0 \\
-1
\end{array}\right) .
\end{aligned}
$$

It follows from systems (41), (42) and (43) that:

$$
\begin{aligned}
& \frac{d w}{d w^{*}}=\frac{d w}{d s^{*}}=\frac{d w}{d s}=0, \\
& \frac{d L}{d w^{*}}=\frac{1}{\beta} \frac{\left(P^{\prime}+L P^{\prime \prime}\right)}{|A|}>0 . \\
& \frac{d L}{d s^{*}}=-\frac{1}{\beta} \frac{\left(P^{\prime}+L P^{\prime \prime}\right)}{|A|}<0 .
\end{aligned}
$$




$$
\begin{aligned}
& \frac{d L}{d s}=\frac{1}{\beta} \frac{\left(2 P^{\prime}+L^{*} P^{\prime \prime}\right)}{|A|}>0 . \\
& \frac{d L^{*}}{d w^{*}}=-\frac{1}{\beta} \frac{\left(2 P^{\prime}+L P^{\prime \prime}\right)}{|A|}<0 . \\
& \frac{d L^{*}}{d s^{*}}=\frac{1}{\beta} \frac{\left(2 P^{\prime}+L P^{\prime \prime}\right)}{|A|}>0 . \\
& \frac{d L^{*}}{d s}=-\frac{1}{\beta} \frac{\left(P^{\prime}+L^{*} P^{\prime \prime}\right)}{|A|}<0 . \\
& \frac{d\left(L+L^{*}\right)}{d w^{*}}=-\frac{1}{\beta} \frac{P^{\prime}}{|A|}<0 . \\
& \frac{d\left(L+L^{*}\right)}{d s^{*}}=\frac{1}{\beta} \frac{P^{\prime}}{|A|}>0 . \\
& \frac{d\left(L+L^{*}\right)}{d s}=\frac{1}{\beta} \frac{P^{\prime}}{|A|}>0 .
\end{aligned}
$$

It follows from equations (44)-(53) that domestic profits and welfare decrease in foreign subsidy and increase in foreign wage regardless of union's wage orientation. 


\section{Appendix B}

\section{Comparative static effects for a union with almost all bargaining}

\section{power}

If the union has almost all bargaining power $(\alpha \approx 1)$ it follows from system (19) that

$$
\begin{aligned}
& \left(\begin{array}{ccc}
\left(\frac{1}{\beta}-1\right) & \left(2 P^{\prime}+L P^{\prime \prime}\right) & \left(P^{\prime}+L P^{\prime \prime}\right) \\
0 & \left(P^{\prime}+L^{*} P^{\prime \prime}\right) & \left(2 P^{\prime}+L^{*} P^{\prime \prime}\right) \\
-1 & \left(P^{\prime}+\frac{\psi}{L^{2}}\right) & P^{\prime}
\end{array}\right)\left(\begin{array}{c}
\frac{d w}{d w^{*}} \\
\frac{d L}{d w^{*}} \\
\frac{d L^{*}}{d w^{*}}
\end{array}\right)=\left(\begin{array}{l}
0 \\
1 \\
0
\end{array}\right), \\
& \left(\begin{array}{ccc}
\left(\frac{1}{\beta}-1\right) & \left(2 P^{\prime}+L P^{\prime \prime}\right) & \left(P^{\prime}+L P^{\prime \prime}\right) \\
0 & \left(P^{\prime}+L^{*} P^{\prime \prime}\right) & \left(2 P^{\prime}+L^{*} P^{\prime \prime}\right) \\
-1 & \left(P^{\prime}+\frac{\psi}{L^{2}}\right) & P^{\prime}
\end{array}\right)\left(\begin{array}{l}
\frac{d w}{d s^{*}} \\
\frac{d L}{d s^{*}} \\
\frac{d L^{*}}{d s^{*}}
\end{array}\right)=\left(\begin{array}{l}
0 \\
-1 \\
0
\end{array}\right), \\
& \left(\begin{array}{ccc}
\left(\frac{1}{\beta}-1\right) & \left(2 P^{\prime}+L P^{\prime \prime}\right) & \left(P^{\prime}+L P^{\prime \prime}\right) \\
0 & \left(P^{\prime}+L^{*} P^{\prime \prime}\right) & \left(2 P^{\prime}+L^{*} P^{\prime \prime}\right) \\
-1 & \left(P^{\prime}+\frac{\psi}{L^{2}}\right) & P^{\prime}
\end{array}\right)\left(\begin{array}{l}
\frac{d w}{d s} \\
\frac{d L}{d s} \\
\frac{d L^{*}}{d s}
\end{array}\right)=\left(\begin{array}{l}
-1 \\
0 \\
-1
\end{array}\right) .
\end{aligned}
$$

It follows from systems (41), (42) and (43) that:

$$
\begin{aligned}
& \frac{d w}{d w^{*}}=\frac{\left[\left(P^{\prime}+L P^{\prime \prime}\right)\left(-\frac{\psi}{L^{2}}\right)+P^{\prime 2}\right]}{|A|}<0, \\
& \frac{d L}{d w^{*}}=\left(\frac{1}{\beta} P^{\prime}+L P^{\prime \prime}\right) \frac{1}{|A|}>0, \quad \text { if } 0<\beta \leq 1 .
\end{aligned}
$$




$$
\begin{aligned}
& \frac{d L^{*}}{d w^{*}}=\left(\left(\frac{1}{\beta}-1\right)\left(P^{\prime}+\frac{\psi}{L^{2}}\right)+\left(2 P^{\prime}+L P^{\prime \prime}\right)\right) \frac{-1}{|A|}<0, \quad \text { if } 0<\beta \leq 1 \\
& \frac{d L}{d s^{*}}=-\left(\frac{1}{\beta} P^{\prime}+L P^{\prime \prime}\right) \frac{1}{|A|}<0, \quad \text { if } 0<\beta \leq 1 . \\
& \frac{d L^{*}}{d s^{*}}=\left(\left(\frac{1}{\beta}-1\right)\left(P^{\prime}+\frac{\psi}{L^{2}}\right)+\left(2 P^{\prime}+L P^{\prime \prime}\right)\right) \frac{1}{|A|}>0, \text { if } 0<\beta \leq 1 .
\end{aligned}
$$




\section{Appendix C}

\section{A reservation profit example}

As an example let us consider a wage neutral union and let the inverse demand

function for the export good be:

$P=P(Q)=a-\left(L+L^{*}\right)$,

where $\mathrm{Q}$ is the market output.

Then, it follows from equations (12), (13) and (15) that:

$\Omega=w-s-w^{*}=\frac{A(\alpha-2)}{3}-a-2 s-w^{*}-\frac{2 A}{3}-\frac{3 \alpha \psi}{A}$,

where $A=w^{*}-s^{*}+a-2 b+2 s$.

Here we observe that $\Omega$ is a function of exogenous variables only. Further, we note that if $\Omega<0$ then the domestic firm will not switch its production abroad. 
Table 2.1

Summary of Results

\begin{tabular}{|l|l|l|l|l|l|l|}
\cline { 2 - 7 } \multicolumn{5}{|c|}{ Wage Neutral Union } & Labor \\
Oriented \\
Union
\end{tabular}

Notes: The sign ' $\leftrightarrow$ ' means that the change in the variable is indeterminate. 


\section{Chapter 3}

\section{Illegal Immigration and Recent U.S. Immigration policy}

\subsection{Introduction}

The issue of illegal immigration to the United States has often attracted attention of policy makers within the past two decades. With the undocumented population reaching 6 million in 1986, the United States Congress passed the Immigration Reform and Control Act. The Act was implemented in 1987 and called for increased enforcement of migration policy, employer sanctions, amnesty for those who could prove continuous residence since 1982 as well as amnesty for seasonal agricultural workers (SAWs) that lived and worked in the country at least 90 days during 1984-1986. The Immigration Reform and Control Act provided legal status to approximately 2.7 million people, which was almost $50 \%$ of those living in the country illegally at the time.

The Immigration Reform and Control Act has raised a lot of controversy in the immigration literature. Reynolds and McCleery (1988) claim that the bill was passed "without any comprehensive economic analysis of its impact on the United States or its main source of undocumented migration, Mexico" and call for a more efficient program of migration regulation than IRCA. Reynolds and McCleery (1988) advocate for cooperation of the two countries and a mutually regulated temporary visa program. Reynolds and McCleery (1988) also suggest taxation of both migrant workers and their employers and using the tax money to finance retraining and adjustment programs in the United States as well as to support the Mexican labor-using investment programs. 
In contrast, Bean et al. (1990) use monthly INS data for 1977-1989 to show that border apprehensions significantly declined following IRCA. Hill and Pearce (1990) claim that at a higher level of INS budget allocation illegal workforce can be reduced substantially. Borjas (1991) uses annual data for 1967-1984 to show that there is a positive correlation between the number of border apprehensions and U.S. expenditure on border apprehensions.

The Immigration Act of 1990 further increased expenditure on border apprehensions and strengthened the U.S. Border Patrol. The Act of 1990 also increased total immigration under an overall flexible cap of 675,000 immigrants: 480,000 familysponsored, 140,000 employment-based and 55,000 "diversity immigrants". The new law increased the per-country quota to 25,620 . Under the previous law, the annual allocation of numerically restricted visas was 270,000 and the per-country quota was set at 20,000 visas per year. In addition, Immigration Act of 1990 revised all grounds for exclusion and deportation and repealed the bar against the admission of communists as nonimmigrants. Special consideration was granted to political refugees escaping from countries with repressive governments.

Often recent legal immigrants from Mexico assist their friends and relatives in migrating to the U.S. illegally by securing a safe passage across the border and providing them with a place to live and work in the United States. In this paper I examine illegal immigration from Mexico to the United States and address two questions. The first question is how responsive illegal immigration is to changes in the number of recent legal immigrants. I test the hypothesis that the number of illegal attempts to enter the United 
States is positively correlated with the number of recent legal immigrants from Mexico. The second question is what effect deportation of Mexicans has on illegal immigration. I hypothesize that, because during the sample period deported illegal immigrants typically faced no criminal penalty, there is no effect at all.

I examine illegal immigration in the U.S. from Mexico and use annual data on the U.S. border apprehensions of illegal aliens and border enforcement for the period from 1968 to 1998, which covers the IRCA in 1986 and the Immigration Act of 1990, and the NAFTA in 1994. I classify aliens (or non-citizens) into three categories: lawful legal immigrants (green-card holders that are authorized to live and work in the United States); non-immigrants (people who are granted nonimmigrant visas to visit, study or work temporarily); illegal immigrants (people with expired immigrant and nonimmigrant visas or without visas). Illegal immigrants are often referred to as undocumented residents.

For most Mexican residents, obtaining a visa may take several years or more (Espenshade, 1994). A Mexican resident who has applied for a visa may choose to migrate illegally to the US while the INS processes his application (Hanson and Spilimbergo, 1999). If the individual is apprehended at the U.S.-Mexico border, he faces no repercussions from the INS as long as he agrees to leave the U.S. voluntarily ${ }^{6}$ and is not processed by the US justice system. In some cases illegal immigrants are involuntarily deported, in which case an immigration judge orders a person physically removed from the country. Normally, apprehended illegal border crossers are transported

\footnotetext{
${ }^{6}$ In 1994 voluntary departures accounted for 95.3 percent of all apprehensions. Figures for previous years are similar (Hanson and Spilimbergo, 1999)
} 
to the nearest U.S.-Mexico border and released there. At that time some of the deported individuals will try to cross the U.S.-Mexico border again and again until they succeed.

Hanson and Spilimbergo (1999) and Majumdar (2002) find strong evidence that apprehensions respond to changes in US immigration policy. Hanson and Spilimbergo (1999) find that apprehensions fell following the passage of legislation in 1986 and rose following the Immigration Act of 1990. Hanson and Spilimbergo (1999), believe that current immigration policy is not effective and call for monitoring employers that are likely to hire illegal aliens as an alternative policy to border enforcement. However, Hanson and Spilimbergo (1999) do not provide any empirical results to show that monitoring employers that are likely to hire illegal aliens indeed will be a better immigration policy.

The contribution of this paper is twofold. First, this paper provides stronger evidence that the immigration policy during the sample period was not effective. Second, the INS devotes a very large fraction of its enforcement resources to policing U.S. borders. I provide empirical evidence in support of the notion that monitoring recent legal immigrants from Mexico that are likely to support undocumented residents in the United States could be a good alternative immigration policy for reducing illegal immigration.

Section 3.2 presents a theory of illegal migration. Data and empirical methodology issues are laid out in Section 3.3. Section 3.4 addresses empirical issues and estimation results. Concluding remarks are given in Section 3.5. 


\subsection{Theory of Illegal Migration}

Consider a Mexican individual deciding whether or not to attempt to cross the U.S.Mexico border illegally. One of the factors that will influence his decision is the probability of being apprehended at the border. Donato et al. (1992) find that the probability of being apprehended by the INS is not significantly correlated with individual characteristics, which allows us to assume that all Mexican individuals have the same probability of apprehension ${ }^{7}$. The probability of apprehension, $P_{t}$, is likely to depend on the level of border enforcement, $H_{t}$, the total number of illegal border crossings, $M_{t}$, and the set of all other relevant factors, $\Psi_{t}$, which may include weather conditions at the border:

$$
P_{t}=P_{t}\left(H_{t}, M_{t}, \Psi_{t}\right)
$$

Economists are of the opinion that migration to the U.S. is negatively correlated with the source-country income per capita (Borjas, 1987), which supports the assumption that the total number of illegal border crossing, $M_{t}$, is likely to depend on Mexican real GDP per capita, $K_{t}$. The total number of attempts to cross the border illegally will be also influenced by the probability of apprehension at the border, $P_{t}$, and information set $\Omega_{t}$, which contains all other relevant information, such as information about the number of different types of visas issued to Mexicans, $V_{t}$, as well as any information that is useful

\footnotetext{
${ }^{7}$ Donato et al. (1992) find that the individual probability of being apprehended by the INS is not significantly correlated with age, previous border-crossing experience and other observable individual characteristics.
} 
to predict future paths of $K_{t}, P_{t}$, and $V_{t}$. The total number of individuals that attempt to cross the border at time $t, M_{t}$, can be expressed as:

$$
M_{t}=M_{t}\left(K_{t}, P_{t}, \Omega_{t}\right)
$$

The individual is assumed to stay forever in the United States once he successfully crossed the border as long-term immigration tends to prevail over seasonal migration (Borjas et al., 1991). Some Mexican residents have immediate family members legally residing in the United States. Since obtaining an immigrant visa may take several years, many decide to enter the country illegally. If the individual is apprehended at the border, he can leave the United States voluntarily and avoid any legal consequences. Otherwise, the individual can stay illegally in the U.S. until his relatives become U.S. citizens and provide him with a legal status.

Now we can express apprehensions at the border, $A_{t}$, by the following function:

$$
A_{t}=P_{t}\left(H_{t}, M_{t}, \Psi_{t}\right) \cdot M_{t}\left(K_{t}, P_{t}, \Omega_{t}\right)
$$

A reduced-form version of equation (3) is used as the basis for the empirical analysis.

\subsection{Data and Empirical Methodology}

Table 3.1 defines variables and provides summary statistics. The data is available from the Mexican Migration Project (MMP) records. MMP gathers and maintains social and demographic data on the lives and characteristics of documented and undocumented Mexican migrants to the United States and makes the collected data available to the public for research. Observations for all variables are annual for the period from 1968 to 1998. The data on apprehensions shows the number of individuals apprehended by the 
U.S. Border Patrol while crossing the U.S. borders illegally. Linewatch hours and border apprehensions over the sample period are shown in Figures A.1 and A.2. Apprehensions have grown substantially over time from approximately 150,000 in 1968 to over 1,600,000 in 1998. Enforcement hours have also grown over the time from under 1,000,000 hours in 1968 to almost 7,000,000 in 1998. IRCA called for an increase in U.S. Border Patrol budget and activities, and the government has further raised expenditure on border enforcement since then.

The major challenge in estimating the number of illegal immigrants entering the United States is that we do not observe the number of illegal entrants. However, we do observe the number of apprehensions at the US-Mexico border and will use it as a proxy for the number of illegal aliens entering the country ${ }^{8}$. Since over the period 1988-1994 over 96 percent of those apprehended by the U.S. Border Patrol were of individuals of Mexican origin (Hanson and Spilimbergo, 1999), I assume that all illegal immigrants are Mexicans residents. Some illegal immigrants are seasonal agricultural workers that work in the U.S. during the season and return to Mexico for the rest of the year (agricultural states such as California and Texas account for over one third of the illegal population residing in the U.S.). As a measure of Mexican income per capita I use Mexican real GDP per capita.

Mexican residents that recently obtained legal status in the United States are likely to support the process of illegal migration of their relatives in Mexico and increase the flow of illegal labor across the U.S.-Mexico border. During the sample period very

\footnotetext{
${ }^{8}$ Hanson and Spilimbergo (1999) and Baishali (2002) among others used the number of apprehensions at the U.S.-Mexico Border as a proxy for the number of illegal entrants.
} 
few legal immigrants from Mexico have been penalized for supporting undocumented residents. In addition, employers of illegal immigrants have been investigated and penalized only on rare occasions.

During the year 1998 over 1.6 million Mexican residents have been apprehended by the U.S. Border patrol at the U.S.-Mexico border. Given that the population of Mexico was less than 95 million in 1998, we observe that almost 6 percent of the Mexican population made a documented attempt to enter the U.S. in 1998.

\subsection{Empirical Issues and Estimation Results}

After transforming all time series into log form I test log apprehensions and log Mexican GDP for stationarity. I find both series to be nonstationary and first difference all continuous time series to account for nonstationarity. It is also noteworthy that all variables, except dummies are in first differences of $\log$ values. Following the apprehension function in equation (3), I estimate apprehensions as a function of the border enforcement, Mexican GDP per capita and a time trend.

I control for other factor which can affect illegal immigration from Mexico by including two additional sets of regressors. The first set of variables includes the IRCA dummy, the Immigration Act of 1990 dummy and the NAFTA dummy. IRCA called for increased border enforcement, sanctions against employers hiring, recruiting, or referring for a fee aliens not authorized to work in the United States as well as amnesty for certain categories of illegal aliens. The Immigration Act of 1990 increased total immigration under an overall flexible cap of 675,000 immigrants: 480,000 family-sponsored, 140,000 employment-based and 55,000 "diversity immigrants". The Act of 1990 also increased 
the per-country quota to 25,620 . Under the previous law, the annual allocation of numerically restricted visas was 270,000 and the per-country quota was set at 20,000 visas per year.

Figure A.5 shows Mexican quota immigrants admitted over the sample period. The number of Mexican quota immigrants admitted rises from an average of 20,584 during 1982-1991 decade to an average of 81,494 during 1992-1998. Further, Immigration Act of 1990 revised all grounds for exclusion and deportation and repealed the bar against the admission of communists as nonimmigrants. Additional provisions of the 1990 Act strengthened the U.S. Border Patrol.

Finally, NAFTA of 1992 called for gradual elimination of trade and investment barriers between Canada, Mexico and the United States. NAFTA became effective on January 1, 1994 and is believed to reduce wage inequality between the participant countries.

The second set of regressors includes current and lagged values of Legal Immigrants. I use one period lagged value of Legal Immigrants since legal immigration from Mexico in the past may affect the incentive for future illegal immigration from Mexico.

One estimation issue that calls for attention is that border enforcement may be determined simultaneously with border apprehensions. The INS may choose to allocate a higher fraction of its budget to border patrol activities if it foresees that increases in attempts to cross the border are likely to take place. I use instrumental variables technique to control for endogeneity of enforcement. My instruments are real US government expenditures on national defense and international relations in the current 
fiscal year; dummy variable for whether a US presidential election will occur in the current calendar year. I also include as instruments current and lagged values of the exogenous regressors.

I consider two measures of border enforcement activity: linewatch hours and the U.S. Border Patrol officers. There is no series for either activity for the U.S.-Mexico border only that span the entire sample period. However, there is nearly perfect correlation between the entire US border series and the U.S.-Mexico border series for the period from 1977 to 1996 (Hanson and Spilimbergo, 1999). Given that the two types of series are highly correlated, I employ the entire U.S. border series on apprehensions, linewatch hours and the U.S. Border Patrol officers for the sample period.

Table 3.2 reports estimation results, in which Border Patrol Officers serves as a measure of Border Enforcement. In column (1a) I estimate apprehensions by OLS, whereas in column (1b) I estimate apprehensions by instrumental variables. In both OLS and IV regressions NAFTA is statistically significant, and the coefficient estimate has a negative sign. This finding offers support for claims that policy initiatives that reduce U.S. wages relative to Mexican wages will decrease the illegal flow of labor across the border.

I also find substantial evidence that apprehensions respond to changes in US immigration policy. The IRCA coefficient estimate is negative and statistically significant in all regressions. Bean et al. (1990) obtain similar results for the period 19771989. These findings support the hypothesis that there was a reduction in illegal border crossings following IRCA. The Immigration Act of 1990 coefficient estimate is positive 
and statistically significant at 10 percent level in both regressions. Hanson and Spilimbergo (1999) also find that IRCA coefficient estimate is negative and the Immigration Act of 1990 coefficient estimate is positive and interprets this result to mean "that the decline in apprehensions following IRCA was temporary, not that the Immigration Act of 1990 somehow increased illegal immigration”.

However, I interpret this result to mean that the Immigration Act of 1990 did in fact increase the illegal northward flow of labor from Mexico. A substantial increase in the number of Mexican quota immigrants, a significant hike in per-country quotas and the extension of amnesty to the undocumented family members of those who had taken advantage of the amnesty provision of IRCA and had taken steps to become U.S. citizens, could have served as a signal to prospective illegal migrants from Mexico that obtaining legal status once in the United States will be easier than before. The fact that the amnesty of 1990 was the second large scale amnesty since 1986 provided additional strong incentives for illegal migration from Mexico.

We see from Tables 3.2 and 3.3 that Mexican real GDP per capita coefficient estimates are negative and highly statistically significant in all regressions. The elasticity of apprehensions with respect to the Mexican real GDP per capita ranges from -1.93 to 2.00 and is statistically significant in all cases. The large negative elasticities I estimate for Mexican real GDP per capita suggest that apprehensions are very sensitive to changes in Mexican real GDP per capita.

Tables 3.2 and 3.3 also show that coefficient estimates of current and one period lagged number of legal immigrants from Mexico is positive and statistically significant in

\footnotetext{
${ }^{9}$ I failed to reject the null hypothesis that the sum of the coefficients on the IRCA and Immigration Act of 1990 is zero at 1, 5 and 10 percent level of significance.
} 
both OLS and IV regressions. This confirms my first hypothesis that recently legalized Mexicans attract undocumented migrants from their home country. The elasticity of apprehensions with respect to current and one period lagged number of legal immigrants from Mexico range from 0.15 to 0.17 and are statistically significant in all cases. Here we observe that apprehensions are much more sensitive to changes in Mexican real GDP than they are to changes in the number of recent legal migrants.

Tables 3.2 and 3.3 also show no statistically significant correlation between Border Apprehensions and Deportations of Mexicans. This finding supports the hypothesis that Deportation of Mexicans has no effect illegal immigration during the sample period.

Table 3.3 reports OLS and IV estimation results, in which linewatch hours serve as a measure of Border Enforcement. Comparing Table 3.2 and Table 3.3 we notice that both OLS and IV regression results are robust to the introduction of linewatch hours as a measure of border enforcement.

Both OLS and IV regression results presented in Tables 3.2 and 3.3 support my conclusion that the Immigration Act of 1990 increased the undocumented labor flow from Mexico. The dummy variable for Immigration Act of 1990 indicates that apprehensions increased by 41 to 43 percent following the passage of legislation in 1990 . While the coefficient estimate for IRCA is negative and significant in all regressions and the dummy variable for IRCA indicates that apprehensions fell by 36.0 to 39.0 percent following the passage of the IRCA, I point out that the decrease in border apprehensions after 1986 may have been due to the fact that the Seasonal Agricultural Workers component have dropped out of the total number of border crossers. I interpret this result 
to mean that IRCA may have stimulated future illegal migration from Mexico rather than decreased it.

\subsection{Concluding remarks}

There is a great deal of confusion about the illegal immigration problem. Typically illegal immigrants are perceived as hard working individuals that want to support their families abroad by performing low-level jobs that Americans have no interest in. However, such a perception is far from being accurate and there are several issues that call for attention. First, illegal migrants, unlike legal immigrants, do not undergo criminal history verification and health screening. This means that a significant portion of border crossers may be individuals with a criminal record or communicable decease. Second, a portion of illegal border crossers is involved in drug trafficking. Third, some illegal immigrants open their own businesses in the United States and interfere with local commerce. Fourth, illegal immigrants create a demand for false identity documents and smuggling networks that could also assist terrorists.

The President of the United States George Bush calls for a new immigration reform that will allow illegal immigrants to obtain a status of a legal worker. George Bush asserts that "some of the jobs being generated in America's growing economy are jobs American citizens are not filling". The President opposes amnesty and "placing undocumented workers on the automatic path to citizenship" and believes that "granting amnesty encourages the violation of our laws and perpetuates illegal immigration". According to the President's plan illegal immigrants that already have a job can apply for the temporary worker program and work legally in the U.S. for up to six years. 
The findings of this paper suggest that large scale amnesties that provide legal status for illegal immigrants should be avoided, as they provide unhealthy stimulus for future illegal immigration. In addition, both illegal immigrants and recent legal immigrants from Mexico that support illegal migrants should be investigated and penalized more effectively. Far more conservative reforms should take place and only after immigration enforcement at the U.S.-Mexican border is strengthened. The immigration reform proposed by the Bush administration is likely to be one of those initiatives and provide a prudent solution to the illegal worker problem. 
Table 3.1

Variable Definitions and Summary Statistics

\begin{tabular}{|c|c|c|}
\hline Variable & Definition & $\begin{array}{c}\text { Mean } \\
\text { (Standard Deviation) }\end{array}$ \\
\hline $\begin{array}{l}\text { Border } \\
\text { apprehensions }\end{array}$ & $\begin{array}{l}\text { Apprehensions by the US Border patrol of } \\
\text { illegal entrants }\end{array}$ & $\begin{array}{c}957,237 \\
(403,859)\end{array}$ \\
\hline Linewatch hours & $\begin{array}{l}\text { Person hours spent by the U.S. Border } \\
\text { Patrol policing U.S. borders }\end{array}$ & $\begin{array}{c}2,268,274 \\
(1,204,106)\end{array}$ \\
\hline Border Patrol Officers & $\begin{array}{l}\text { Number of Border Patrol Officers } \\
\text { policing the U.S. border }\end{array}$ & $\begin{array}{c}3,137 \\
(1,606)\end{array}$ \\
\hline Legal Immigrants & $\begin{array}{l}\text { Number of Legal Immigrants from } \\
\text { Mexico }\end{array}$ & $\begin{array}{c}140,604 \\
(195,956)\end{array}$ \\
\hline Deportations of Mexicans & $\begin{array}{l}\text { Number of Mexicans Deported from the } \\
\text { United States }\end{array}$ & $\begin{array}{l}22,628 \\
(26,677)\end{array}$ \\
\hline Mexican GDP & $\begin{array}{l}\text { Mexican real GDP } \\
\text { per capita }\end{array}$ & $\begin{array}{c}604,995 \\
(198,026)\end{array}$ \\
\hline NAFTA & $\begin{array}{l}=1 \text { if fiscal year is } 1995 \text { or later, when } \\
\text { North American Free Trade Agreement } \\
\text { Of } 1994 \text { was implemented }\end{array}$ & $\begin{array}{c}0.161 \\
(0.374)\end{array}$ \\
\hline Immigration Act 1990 & $\begin{array}{l}=1 \text { if fiscal year is } 1992 \text { or later, when } \\
\text { Immigration Act of } 1990 \text { was } \\
\text { implemented }\end{array}$ & $\begin{array}{c}0.290 \\
(0.461)\end{array}$ \\
\hline IRCA & $\begin{array}{l}=1 \text { if fiscal year is } 1987 \text { and later, when } \\
\text { Immigration Reform and Control Act was } \\
\text { implemented }\end{array}$ & $\begin{array}{c}0.419 \\
(0.501)\end{array}$ \\
\hline Defense spending & $\begin{array}{l}\text { U.S. government expenditures on } \\
\text { National Defense and International } \\
\text { Relations(billions of US dollars) }\end{array}$ & $\begin{array}{l}200 \\
(95)\end{array}$ \\
\hline Presidential election & $\begin{array}{l}=1 \text { if there is an upcoming presidential } \\
\text { election in the current calendar year }\end{array}$ & $\begin{array}{c}0.258 \\
(0.445)\end{array}$ \\
\hline Congressional election & $\begin{array}{l}=1 \text { if there is an upcoming congressional } \\
\text { election in the current calendar year }\end{array}$ & $\begin{array}{c}0.258 \\
(0.445)\end{array}$ \\
\hline
\end{tabular}


Table 3.2

First-Difference Specification of Border Apprehensions

with Border Patrol Officers as Measure of Enforcement

Dependent Variable: Border Apprehensions

\begin{tabular}{lll}
\hline $\begin{array}{l}\text { Method } \\
\text { Variable }\end{array}$ & $\begin{array}{l}\text { OLS 1 } \\
\mathbf{( 1 a )}\end{array}$ & $\begin{array}{l}\text { IV 1 } \\
\mathbf{( 1 b )}\end{array}$ \\
\hline Constant & $0.663(4.58)^{* * *}$ & $0.637(3.95)^{* * *}$ \\
Legal Immigrants & $0.161(2.35)^{* * *}$ & $0.167(2.24)^{* *}$ \\
(Legal Immigrants)-1 & $0.159(2.66)^{* * *}$ & $0.161(2.55)^{* *}$ \\
Deportations of Mexicans & $-0.023(-0.16)$ & $-0.058(-0.33)$ \\
Border Patrol Officers & $0.118(0.27)$ & $0.690(0.46)$ \\
Mexican real GDP per capita & $-1.985(-3.96)^{* * *}$ & $-1.930(-3.58)^{* * *}$ \\
NAFTA & $-0.370(-2.61)^{* * *}$ & $-0.385(-2.45)^{* *}$ \\
Immigration Act of 1990 & $0.421(2.03)^{*}$ & $0.410(1.83)^{*}$ \\
IRCA & $-0.233(-1.77)^{*}$ & $-0.234(-1.81)^{*}$ \\
TIME & $-0.065(-2.91)^{* * *}$ & $-0.064(-2.73)^{* * *}$ \\
(TIME) ${ }^{2}$ & $0.002(2.04)^{* *}$ & $0.001(1.89)^{*}$ \\
Adjusted R-squared & & 0.522 \\
Durbin-Watson & 0.565 & 1.902 \\
Number of observations & 2.090 & 29 \\
\hline
\end{tabular}

Notes: All continuous variables are in first differences of log values. In column (1b) I instrument for Border Patrol Officers. Instruments are real US government expenditures on Defense and International Relations in the current fiscal year; dummy variable for whether a US presidential election will occur in the current calendar year; current and lagged values of the exogenous regressors. Residuals are stationary in both OLS and IV regressions. 
Table 3.3

First-Difference Specification of Border Apprehensions with Linewatch Hours as Measure of Enforcement Dependent Variable: Border Apprehensions

\begin{tabular}{|c|c|c|}
\hline $\begin{array}{l}\text { Method } \\
\text { Variable }\end{array}$ & $\begin{array}{l}\text { OLS } 1 \\
\text { (1a) }\end{array}$ & $\begin{array}{l}\text { IV 1 } \\
(1 b)\end{array}$ \\
\hline Constant & $0.655(4.54)^{* * *}$ & $0.642(3.91)^{* * *}$ \\
\hline Legal Immigrants & $0.152(2.11)^{* *}$ & $0.156(2.11)^{* *}$ \\
\hline 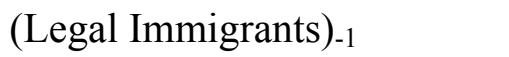 & $0.158(2.67)^{* * *}$ & $0.163(2.75) * * *$ \\
\hline Deportations of Mexicans & $-0.038(-0.26)$ & $-0.045(-0.22)$ \\
\hline Linewatch Hours & $0.112(0.42)$ & $0.159(0.21)$ \\
\hline Mexican real GDP per capita & $-2.000(-3.99)^{* * *}$ & $-1.988(-3.93) * * *$ \\
\hline NAFTA & $-0.361(-2.58)^{* * *}$ & $-0.373(-2.54)^{* *}$ \\
\hline Immigration Act of 1990 & $0.414(2.00)^{*}$ & $0.434(2.09)^{*}$ \\
\hline IRCA & $-0.230(-1.83)^{*}$ & $-0.245(-2.07)^{*}$ \\
\hline TIME & $-0.063(-2.88) * * *$ & $-0.062(-2.60) * * *$ \\
\hline$(\mathrm{TIME})^{2}$ & $0.002(1.98)^{*}$ & $0.002(1.83)^{*}$ \\
\hline Adjusted R-squared & 0.568 & 0.565 \\
\hline Durbin-Watson & 2.088 & 2.097 \\
\hline Number of observations & 29 & 29 \\
\hline
\end{tabular}

Notes: All continuous variables are in first differences of log values. In column (1b) I instrument for Border Patrol Officers. Instruments are real US government expenditures on Defense and International Relations in the current fiscal year; dummy variable for whether a US presidential election will occur in the current calendar year; current and lagged values of the exogenous regressors. Residuals are stationary in both OLS and IV regressions. 
Figure 3.1

Enforcement of the U.S. Border Data, 1968-1998

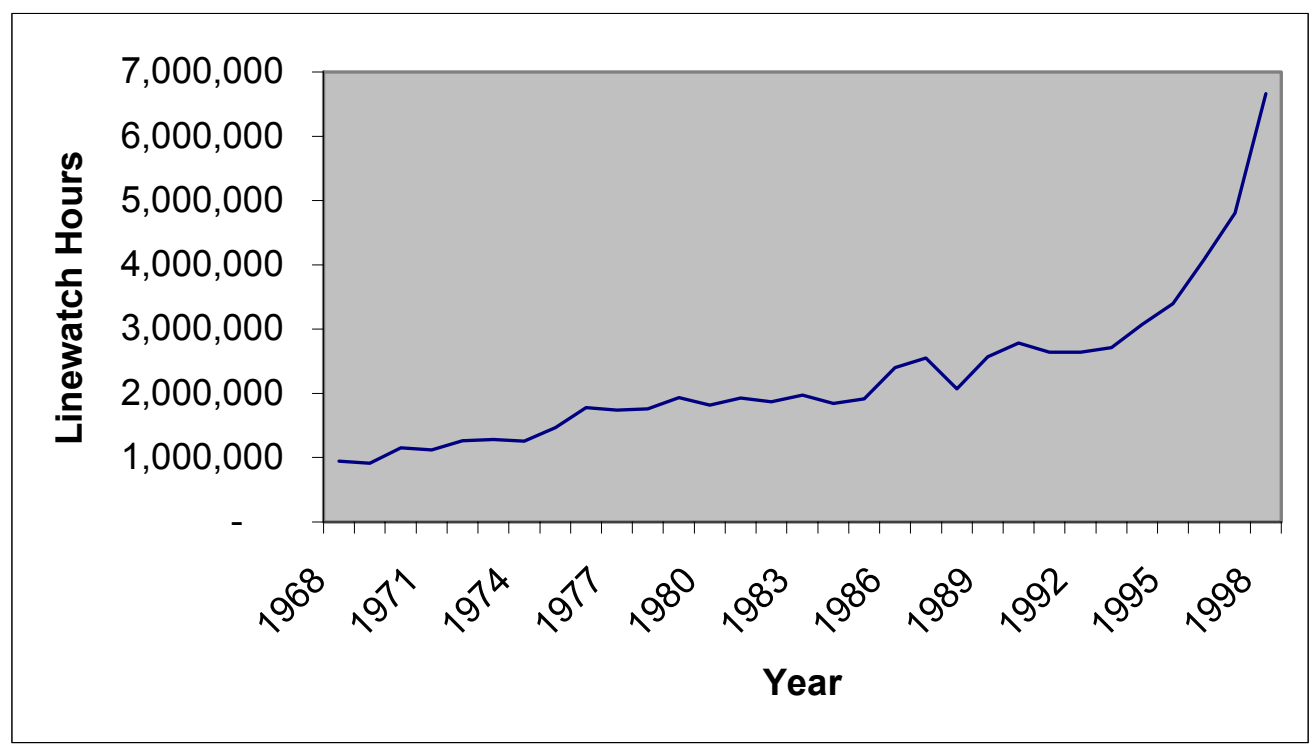

Figure 3.2

Apprehensions at the U.S. border

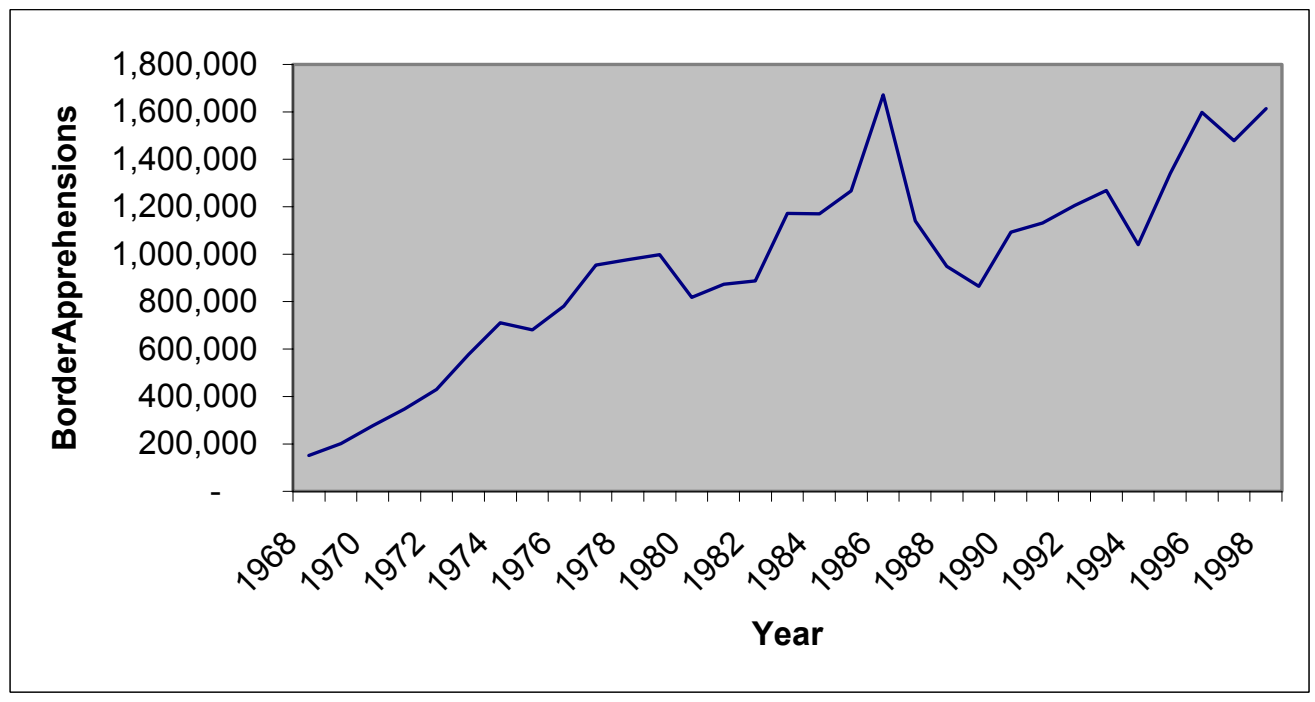


Figure 3.3

Legal Immigrants from Mexico

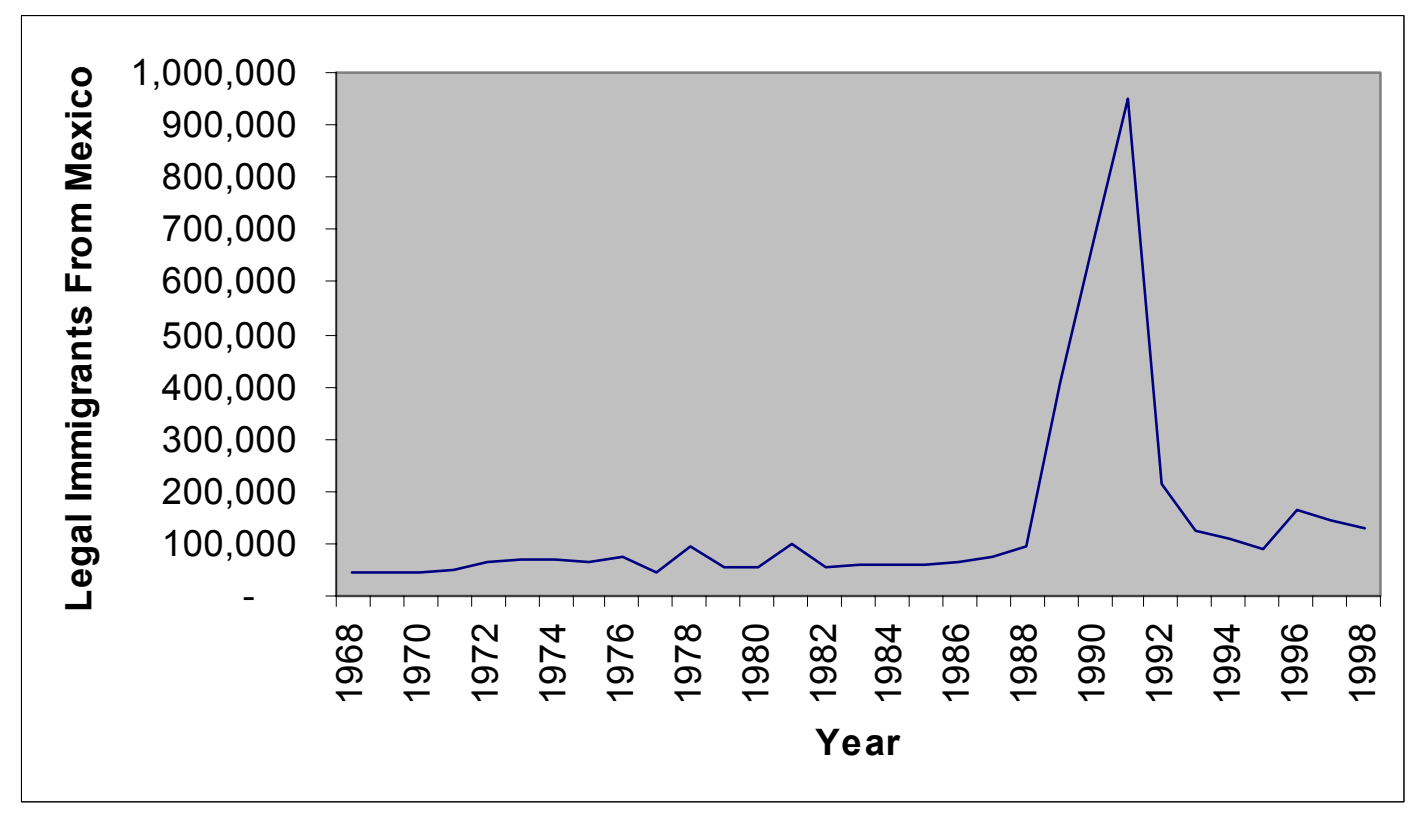

Figure 3.4

Deportations of Mexicans

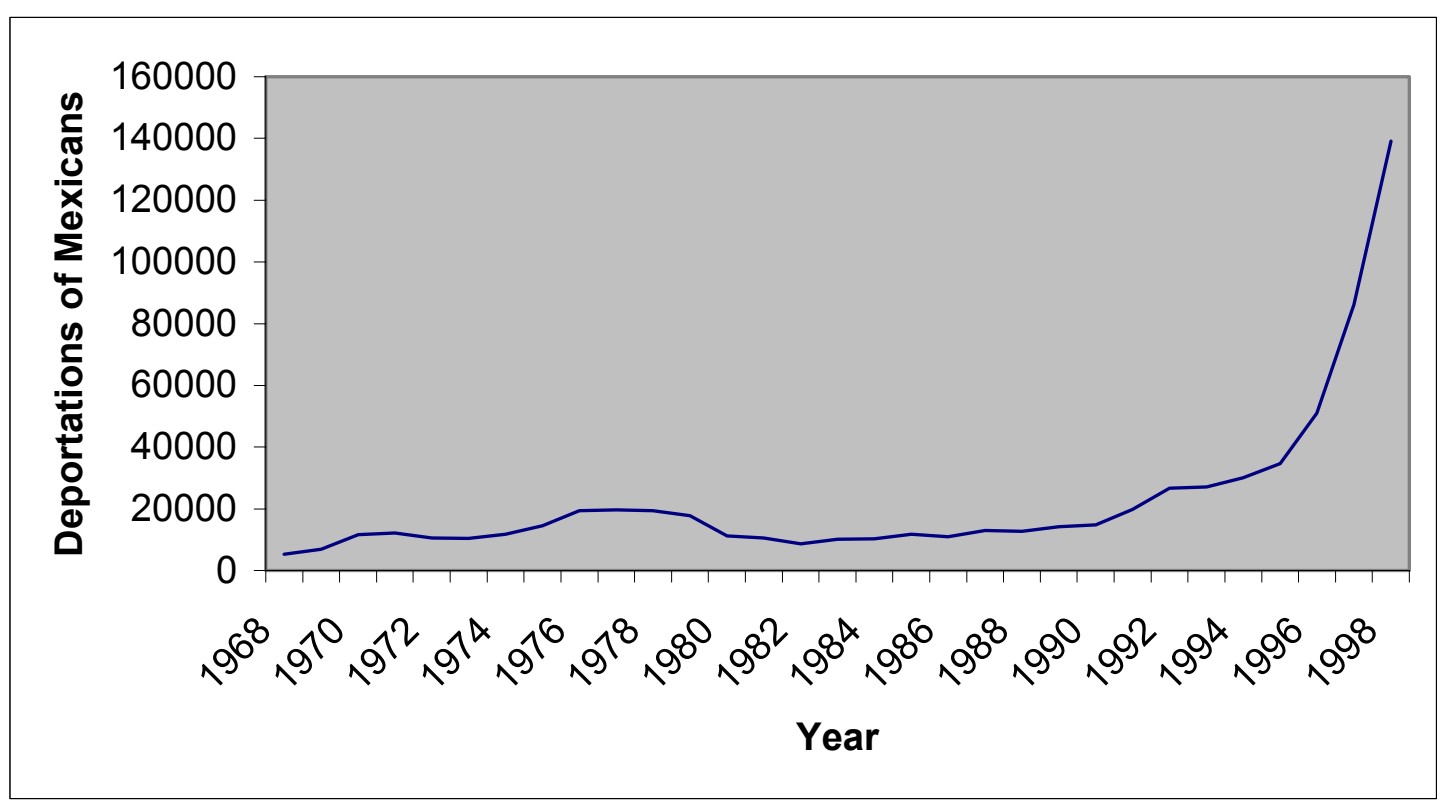


Figure 3.5

Mexican Quota Immigrants Admitted

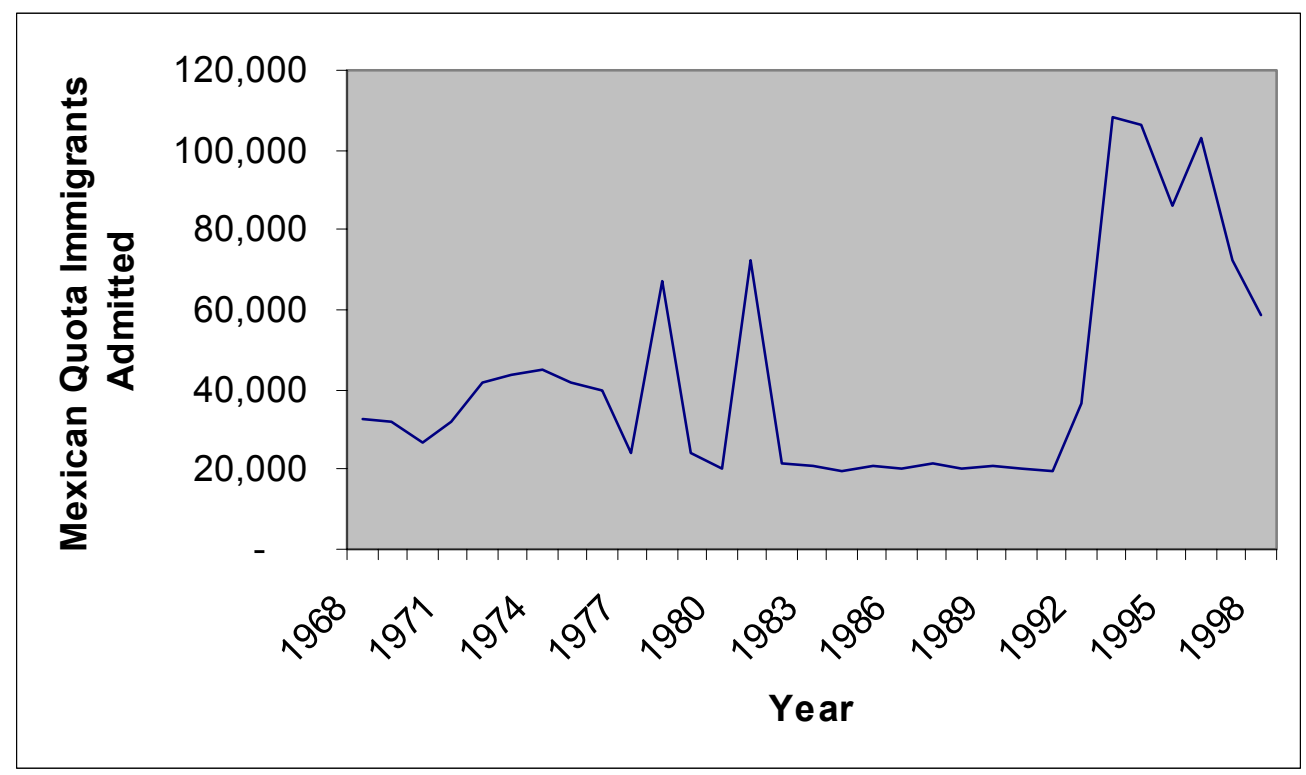




\section{Chapter 4}

\section{A Gravity Model of Legal Immigration to the United States}

\subsection{Introduction}

Legal Immigration to the United States has attracted close attention of policy makers over the past four decades. Until the 1960s immigrants from Europe had a preferential treatment under the existing immigration laws and national origin quotas. For instance, under the McCarran-Walter Act of 1952 the quota for European immigrants was almost 150,000 and the quota for Asian immigrants was under 3,000. Immigrants from Ireland, Germany and Britain dominated the inflow of legal immigrants.

In 1965, President Lyndon Johnson signed the Immigration Act of 1965 that allowed more individuals from third world countries immigrate to the United States. The main purpose of the Immigration Act of 1965 was eliminating discrimination in immigration and allowing professional workers into the country regardless of their ethnicity and national origin. Separate quotas were established for Western and Eastern hemispheres as well as a system of preferences that favored family reunification. An annual limitation of 170,000 visas was established for immigrants from eastern hemisphere countries, with a per country limit of 20,000. The annual limitation from the western hemisphere was set at 120,000 immigrants with "no national limitations".

In 1986 the Immigration Reform and Control Act legalized undocumented immigrants lived in the country since 1982. The Act also called for increased enforcement of migration policy, employer sanctions as well as amnesty for seasonal agricultural workers that lived and worked in the country at least 90 days during 19841986. The IRCA provided legal status to nearly 2.7 million illegal migrants. 
Finally, The Immigration Act of 1990 raised the overall limitation quota and increased expenditure on the U.S. Border Patrol. The Act of 1990 increased total immigration under a new overall flexible cap of 675,000 immigrants. The new law increased the per-country quota to 25,620. Further, Immigration Act of 1990 revised all grounds for exclusion and deportation and repealed the bar against the admission of communists as nonimmigrants. Special consideration was granted to political refugees escaping from countries with repressive governments.

There is has been a lot of debate about decreasing quality of US immigrants between 1950s and 1980s (Borjas 1987, 1994) and a number of studies of the determinants of immigration by source country (Borjas 1987, Kamemera et. al. 2000, Clark et. al 2002, Mayda 2003). Economists believe that individuals compare the potential incomes in the United States with the incomes in the home countries, and make the migration decision based on those income differentials (Borjas 1987). Income inequality is also considered to be an important factor affecting decision to emigrate from the source country. Borjas (1987) measures income inequality as the ratio of household income of the top 10 percent of the households to the income of the bottom 20 percent of the households.

Borjas (1987) conducts empirical analysis of the earnings of immigrants from 41 source countries for 1951-80 that account for 90.4 percent of total immigration to the United States. Borjas (1987) finds that immigrants from countries that have high levels of GNP, low levels of inequality and politically competitive systems have high incomes relative to their skills. Borjas (1987) documents the decrease in Western European immigrant flows as well as an increase in immigration from Asia and Latin America. 
Borjas (1987) also shows that the probability that an individual migrated to the U.S. is negatively related to the source country GNP per capita and distance to the United States and positively related to the individuals English language proficiency. In particular, Borjas (1987) shows that individuals from Western European countries do quite well in the United States, and their cohorts exhibit increase in earnings, while persons from less developed countries do not perform well in the U.S. labor market and their cohorts exhibit decrease in earnings.

In addition, Borjas (1987) reports that Mexico is responsible for the highest number of immigrants over the sample period. From 1951 to 1980 almost 1.4 million Mexican residents immigrated to the United States. Canada, Cuba and Germany are responsible for over 600,000 immigrants each over the sample period.

Mayda (2003) empirically investigates determinants of migration inflows into fourteen OECD countries by country of origin, between 1980 and 1996. Mayda (2003) also finds evidence of negative impact on emigration rates of distance between destination and source country. Mayda (2003) documents that the distance effect is negative, significant and quite steady across specifications. Mayda (2003) uses annual data on immigration inflows to fourteen OECD countries by country of origin. Mayda (2003) finds that improvements in income opportunities in destination countries significantly increase the emigration rate and are very robust to changes in the specifications of the empirical model.

Mayda (2003) also finds that the impact of per worker GDP of the source country is smaller than that of the pull factors and is at times insignificant. While most of the work, including my paper, focuses on a single destination country (Borjas and Bratsberg, 
1996, Clark et al. 2002, and Kamemera et al. 2000) or a single origin country, Mayda (2003) analyzes a multitude of origins and destinations. However, Mayda (2003) does not consider populations of either source or destination country.

Kamemera et al. (2000) conduct a gravity model analysis of international migration to the United States. To empirically test their model, Kamemera et al. (2000) used panel data for the decade 1976-1986, including a wide range of variables both for the United States and 70 source countries. Migration was negatively related to distance, source country's income and political instability and positively related to the source country's instability. Kamemera et al. (2000) pioneered the use of political variables in a gravity model. The gravity model derived by Kamemera et al. (2000) provides results similar to Borjas (1989) and Wadycki (1973). Kamemera et al. (2000) present several competing theoretical models and use specification tests to choose between them.

The present study uses a modified gravity model to examine the major determinants of migrant flows to the United States. The specific objectives of this study are: to analyze the effect of demographic, economic and political factors on the propensity to migrate. The time period of this study is from 1996-2000 and 101 countries are covered for a total of 505 observations of migration flows to the United States.

The remainder of this paper is arranged as follows. The gravity model of migration to the United States is derived in Section 4.2. Section 4.3 discusses the estimated results. Section 4.4 provides concluding remarks.

\subsection{A Gravity Model of Migration to the United States}

\subsubsection{Theoretical Background}


Economists view migration as an investment decision (Sjaastad, 1962; Greenwood 1985; Stark 1991). Similar to Greenwood (1975), Borjas (1989) assumes that an individual migrates if the expected discounted difference in the stream of income between the source and destination country exceeds moving costs. Potential migrants compare all possible destination countries and choose a country that provides the best opportunities. Migrant flows depend on the source and destination country's characteristics as well as on the characteristics of migrants themselves.

A model of immigration proposed by Borjas (1989) includes variables which influence the number and composition of immigrant flows. However, Kamemera, Oguledo and Davis (2000) to my knowledge are the first to test empirically the suggested elasticities of migration with respect to the unique variables that Borjas and Greenwood identified in their models. Gravity models similar to Kamemera et al. (2000) received very limited attention in migration studies and more empirical studies of gravity models are needed.

The economic theory of immigration is far from being developed (Borjas, 1989). However, the supply and demand for migrants can be linked systematically to size of the population and income of both source and destination country (Kamemera et al.,2000). Kamemera et al. (2000) employed a gravity model of immigration to the United States. In this paper I derive a modified version of that model.

Denoting the source country $i$ and the United States $j$, the migrant flow from the source country to the United States will depend on potential push factors, $S_{i}$, and pull factors, $D_{i}$. The push and pull factors are a function of income $y$ and population $n$ 
.Therefore, $S_{i}=b_{0} y_{i}^{b_{1}} n_{i}^{b_{2}}$ and $D_{j}=c_{0} y_{j}^{c_{1}} n_{j}^{c_{2}}$. Combining $S_{i}$ and $D_{i}$ we can represent the migration flow equation as:

$$
F_{i j}=\frac{a_{0} S_{i}^{a_{1}} D_{j}^{a_{2}}}{R_{i j}^{a_{3}}}
$$

where $R_{i j}$ are factors aiding or restraining flows of migrants from the source country to the U.S., such as cost of travel from the source country to the United States and cost of information on the alternative host countries.

Transforming equation (1) into a log form and replacing terms by their equivalents, yields the migration model as:

$$
m_{i j}=\alpha_{0}+\alpha_{1} n_{i}+\alpha_{2} n_{j}+\alpha_{3} y_{i}+\alpha_{4} y_{j}+\alpha_{5} c_{i j}+z(\cdot)
$$

where $c_{i j}$ and $z(\cdot)$ replace $R_{i j}$ in equation (1) and denote travel costs and all other factors facilitating or restraining migration flows. Equation (2), where $z(\cdot)$ is just an error function, is a gravity model of migration proposed by Sjaastad (1962), Greenwood (1975) and Borjas $(1987,1989)$. A migration flow from country $i$ to country $j$ is a positive (negative) function of population size in the source (destination) country, a positive (negative) function of the income in the destination (source) country, and a negative function of monetary and psychic costs of moving to the destination country.

To estimate empirically equation 2 , arguments of $z(\cdot)$ need to be identified. Borjas (1989) suggest that possible arguments of function $z(\cdot)$ may be unemployment and political and civil freedom. Gastil (1987) suggests that political freedom and liberties are important and should be included in an empirical investigation. 


\subsubsection{Data and Empirical Methodology}

Data on immigrants admitted by region and country of birth is available from the Statistical Yearbook of the INS for fiscal years 1996-2000. Data on population, income and distance to the U.S are available from World Bank database. Index of Freedom comes from the Heritage Foundation ${ }^{10}$.

The Index of Freedom measures a country's economic freedom based on 50 independent variables divided into 10 broad factors of economic freedom. These factors are: trade policy, fiscal burden of government, government intervention in the economy, monetary policy, capital flows and foreign investment, banking and finance, wages and prices, property rights, regulation and black market. The higher the index of economic freedom, the greater the level of government interference in the economy and the less economic freedom a country enjoys.

I attempt to capture determinants of the emigration rate to the United States in the following specification:

$$
\begin{aligned}
& (\text { mig })_{i}=\beta_{0}+\beta_{1} d_{i j}+\beta_{2} n_{i}+\beta_{3} n_{j}+\beta_{4} y_{i}+\beta_{5} y_{j}+ \\
& +\beta_{6} \text { MigrantStock }+\beta_{7} \text { English }+\beta_{8} \text { FreedomIndex }+ \\
& +\beta_{9} \text { Unemployment }+\beta_{10} E U+ \\
& +\beta_{11} A F+\beta_{12} A S+\beta_{13} S A+\beta_{14} C A+\beta_{15} O C .
\end{aligned}
$$

The left-hand side variable is the total number of immigrants admitted to the US by country of birth. The first five variables are gravitational demographic variables: distance $d_{i j}$, population $n_{i}, n_{j}$, and income $y_{i}, y_{j}$ which are discussed in the base model

\footnotetext{
${ }^{10}$ The Heritage Foundation is a conservative think tank located in Washington DC. More information about Heritage Foundation is available online at www.heritage.org.
} 
in equation $2 ; \beta_{1}<0, \beta_{2}>0, \beta_{3}<0, \beta_{4}<0, \beta_{5}>0$. As a measure of income in both source and destination country I use GDP per capita.

Economists believe that distance negatively affects migration since it is more costly to acquire information ex-ante about distant countries (Greenwood (1997)). In addition, the further apart the source and destination country are, the higher the travel cost are likely to be for both the initial move and visits back home. Mayda (2003) also suggests that remote destinations may discourage migration because they require longer travel time and thus higher foregone earnings.

Increase in immigrant stock in the US decreases migration costs for potential immigrants. Migration costs are also associated with whether the source country is predominantly English-speaking; thus we expect that $\beta_{6}>0, \beta_{7}>0$. Further, I hypothesize that migration flows are higher from countries that enjoy less economic freedom; $\beta_{8}>0$. The unemployment rate in the US is included to identify the impact of labor unemployment on migration rates. It is expected that rising unemployment in the US discourages inflow of migrants; $\beta_{9}<0$.

Finally, countries of origin were grouped into seven regions. The seven regions are represented by six dummy variables: $E U(=1$ if the origin continent is Europe; 0, otherwise), $A F$ (=1 if the origin continent is Africa; 0 otherwise), $A S$ (=1 if the origin continent is Asia; 0, otherwise), $S A$ (=1 if the origin continent is South America, 0, otherwise), $C A$ (=1 if the origin continent is Central America and the Caribbean; 0, otherwise $), O C(=1$ if the origin continent is Oceania; 0 , otherwise). These dummy variables are used to estimate the migration effect of different continents or regions. 
All non-dummy variables that I use in estimation are expressed in logs, so the estimated coefficients represent impact elasticities.

\subsection{Econometric results}

I estimate my model on balanced panel data for immigration to the United States by source country for 101 countries across 5 years from 1996 to $2000^{11}$. Immigration from the 101 countries under this study accounts for 77.8 percent of all immigration to the United States during the period. Table A1 provides the list of countries included in the migration flow analysis. Table A2, at the end of the paper, presents the estimation results $^{12}$. I perform a Hausman test to choose between Fixed Effects and Random Effects models and find that the p-value is not significant at $10 \%$ level. Thus, the test suggests the use of the Random Effects model.

The estimated results show a systematic pattern, broadly consistent with theoretical predictions. The distance impairs migration flows to the United States, as expected. An increase in distance between a source country and the United States increases transportation and logistic costs and reduces the propensity to migrate ${ }^{13}$. The estimated elasticity coefficient on distance has the expected sign and is significant at

\footnotetext{
${ }^{11}$ In present study I include important countries that Clark, Hatton and Williamson (2002) omit in their study, such as Ethiopia, Somalia and Nigeria in Africa; Vietnam, Iraq and Lebanon in Asia; Cuba and Haiti in the Caribbean.

${ }^{12}$ In addition, I modify equation (3) by adding a dummy for communist or ex-communist source country and report estimation results in Table A3. I find no statistical evidence in support of the notion that communist or ex-communist status of the origin had any effects on migration flows during the period of study.

${ }^{13}$ Since transportation costs are not readily available, most studies use distance as a proxy for transportation costs.
} 
$1.0 \%$ level $^{14}$. This result is similar to the results of Mayda (2003) and Kamemera et al. (2000).

The estimated coefficient on income per capita for the US is insignificant at $5.0 \%$ level, however it has the expected sign. It appears that income has no significant pull effect in the model under present study. The estimated coefficient on income per capita for the source country is significant at 5.0\% level and has a positive sign. A higher GDP per worker in the source country lowers the incentive to migrate, but it also makes it more likely that a bigger portion of population will be able to afford to move ${ }^{15}$.

The estimated coefficient on origin population has a positive sign, as expected, and is significantly different from zero at $1.0 \%$ level. This implies that continued growth of population in the source countries will lead to increased migrant flows. The magnitude of the estimated elasticity on origin population is smaller than 1.0, which shows that migration flows are not sensitive to demography of source countries. However, the coefficient on US population is not significant at $10 \%$ level. It appears that growth of US population does not affect the size of migrant flows.

The estimated coefficient on immigrant stock in the US is significant at $1.0 \%$ level, and has the expected sign. The magnitude of the estimated elasticity on origin population is substantially larger than 1.0 , which shows that migration flows are highly sensitive to the stock of migrants in the US.

\footnotetext{
${ }^{14}$ Mayda (2003) finds that among the variables affecting the costs of migration, distance is one of the most important ones.

${ }^{15}$ Migrants typically have to pay fixed costs to move. If the source country's GDP per capita is low enough and credit markets are not perfect, some potential migrants will not be able to afford to move.
} 
I also find that the estimated coefficient on English language proficiency has the expected sign and is significant at $1 \% \operatorname{level}^{16}$. This result is similar to that of Clark, Hatton and Williamson (2002) in both sign and level of significance.

The unemployment variable in the model has an unexpected sign and is significant at $1 \%$ level. This result suggests that migrant flows to the United States may be unaffected by the US unemployment.

The estimated coefficient on source country's Index of Freedom has expected sign and is significant at $5 \%$ level $^{17}$. Recall that higher index of Economic Freedom indicates less economic freedom. In other words, decrease in economic freedom in the source country is associated with increased migration to the United States.

The variable representing index of economic freedom indicates an increase in migrant flows to the US. The estimated elasticity is high and significant at $1.0 \%$ level. The present study suggests that future migration studies should include variables representing the overall level of source country's government interference in the economy, such as Index of Economic Freedom.

\subsection{Concluding remarks}

In this paper I develop a traditional gravity model and adjust it to include political and economic characteristic of source and destination countries. Special consideration was given to the Index of Economic Freedom, which is an important variable omitted in all

\footnotetext{
${ }^{16}$ In contrast, Kamemera et al. (2000) find no statistical evidence that English language proficiency has effects on migration flows to the United States.

${ }^{17}$ Kamemera et al. (2000) find that improved financial performance and increased flow of foreign credit has a positive impact on propensity to migrate.
} 
previous studies. I also find that population and income variables are important factors in explaining migration flows.

Immigrant stock-a popular proxy for "chain migration" effect-was found to be a very significant determinant of migration flows to the US. Despite importance of "chain migration" effects, proxies for these effects are often omitted from migration analysis. The elasticity of Immigrant Stock is significant at $1.0 \%$ percent level. In addition, the results of this study show that increase in source country's income opportunities has a positive net effect on migration flows.

Finally, the overall findings of present study are in accord with those of previous research. The gravity model derived in this paper provides results similar to Kamemera et al. (2000), Clark and Hatton (2002) and Mayda (2003). Their results are similar to the results of present study in sign and significance. However, the comparison is not ideal due to differences in specification as well as the period of estimation and sample size. 


\section{Table 4.1}

\section{List of countries included in the migration flow analysis}

\begin{tabular}{|c|c|}
\hline Continent/Region & Countries \\
\hline Europe & $\begin{array}{l}\text { Austria, Belgium, Denmark, Finland, France, Germany, Greece, } \\
\text { Hungary, Ireland, Italy, Malta, Netherlands, Norway, Poland, } \\
\text { Portugal, Spain, Sweden, Switzerland, United Kingdom }\end{array}$ \\
\hline Africa & $\begin{array}{c}\text { Algeria, Angola, Benin, Burkina Faso, Burundi, Cen. African } \\
\text { Rep., Congo Dem. Rep., Egypt, Ethiopia, Gabon, Ghana, Guinea, } \\
\text { Ghana, Kenya, Korea Republic, Madagascar, Malawi, Mali, } \\
\text { Mauritania, Morocco, Mozambique, Niger, Nigeria, Sierra Leone, } \\
\text { Senegal, South Africa, Sudan, Tanzania, Tunisia, Uganda, } \\
\text { Zambia, Zimbabwe }\end{array}$ \\
\hline Asia & $\begin{array}{c}\text { Bahrain, Bangladesh, China, Cyprus, Hong Kong, India, } \\
\text { Indonesia, Iran, Israel, Japan, Jordan, Kuwait, Malaysia, Nepal, } \\
\text { Pakistan, Philippines, Saudi Arabia, Singapore, Sri Lanka, } \\
\text { Turkey, Yemen }\end{array}$ \\
\hline North America & United States, Canada \\
\hline Central America & Costa Rica, El Salvador, Honduras, Nicaragua, Panama, Mexico \\
\hline Caribbean & $\begin{array}{c}\text { Bahamas, Barbados, Dominican Republic, Haiti, Jamaica, } \\
\text { Trinidad and Tobago }\end{array}$ \\
\hline South America & $\begin{array}{c}\text { Argentina, Bolivia, Brazil, Chile, Colombia, Ecuador, Paraguay, } \\
\text { Peru, Suriname, Uruguay, Venezuela }\end{array}$ \\
\hline Oceania & Australia, Fiji, New Zealand, Papua New Guinea \\
\hline
\end{tabular}

Source: Statistical Yearbook of the Immigration and Naturalization Service for 2001, Table 3 . 


\section{Table 4.2 \\ Immigration Rate Regressions \\ Dependent Variable: Immigrants admitted by country of birth}

\section{Variable/coefficients}

(1)

(2)

$$
\begin{aligned}
& -242.693(-0.80) \\
& -1.994(-3.76)^{* * *} \\
& 9.979(0.56) \\
& 0.847(9.15)^{* * *} \\
& 2.332(0.44) \\
& 0.182(1.96)^{* *} \\
& 6.621(4.86)^{* * *} \\
& 0.062(1.91)^{* *} \\
& 8.453(4.96)^{* * *} \\
& 0.813(2.50)^{* * *} \\
& 3.767(2.00)^{* *} \\
& 3.633(1.78)^{* *} \\
& 5.632(2.67)^{* * *} \\
& 5.422(3.21)^{* * *} \\
& 5.232(2.75)^{* * *} \\
& 5.337(2.47)^{* * *} \\
& 0.40 \\
& 0.2959 \\
& 505
\end{aligned}
$$
$-238.647(-0.78)$
$-2.064(-3.87)^{* * *}$
$9.787(0.54)$
$0.845(9.15)^{* * *}$
$2.358(0.45)$
$0.204(2.13)^{* *}$
$6.609(4.85)^{* * *}$
$0.060(1.87)^{*}$
$8.469(4.96)^{* * *}$
$0.883(2.66)^{* * *}$
$3.947(2.09)^{* *}$
$3.881(1.89)^{* *}$
$5.885(2.77)^{* * *}$
$5.601(3.31)^{* * *}$
$5.509(2.87)^{* * *}$
$5.596(2.57)^{* * *}$
$-0.440(-0.96)$
0.396
0.2962
505

Notes: All non-dummy variables are in log values. T-statistics are in parenthesis. RMS indicates mean square error. 
Table 4.3

Source Area Composition of US Immigration, 1996-2000 (percent of total from each source)

\begin{tabular}{|l|l|l|l|l|l|}
\hline Region of origin & 1996 & 1997 & 1998 & 1999 & 2000 \\
\hline Europe & 6.3 & 5.6 & 5.5 & 5.2 & 5.8 \\
\hline Asia & 48.8 & 49.2 & 48.3 & 48.7 & 46.9 \\
\hline Africa & 4.9 & 5.2 & 5.1 & 4.9 & 4.4 \\
\hline Americas & 38.5 & 38.5 & 40.6 & 41.7 & 42.4 \\
\hline Canada & 1.7 & 1.5 & 1.6 & 1.4 & 1.9 \\
\hline Mexico & 17.9 & 18.4 & 20.1 & 22.9 & 20.5 \\
\hline Caribbean & 9.4 & 8.5 & 8.4 & 6.0 & 7.5 \\
\hline Central America & 3.8 & 4.4 & 4.2 & 5.5 & 6.6 \\
\hline South America & 5.7 & 5.7 & 6.3 & 5.9 & 5.9 \\
\hline Oceania & 0.5 & 0.5 & 0.5 & 0.5 & 0.5 \\
\hline & & & & & \\
\hline Total (thousands) & 915,900 & 798,378 & 654,451 & 646,568 & 849,807 \\
\hline
\end{tabular}

Source: Statistical Yearbook of the Immigration and Naturalization Service for 2001, Table 3. Notes: Immigrants are classified by country of last residence. 


\section{Chapter 5}

\section{Summary and Conclusions}

This dissertation has explored issues of legal and illegal immigration and outsourcing. The first essay develops a simple static model of a unionized domestic firm and a foreign firm, both producing a homogeneous good and competing in the third country's market. The domestic firm has an option to shift all of its production abroad and produce in the fourth country in order to reduce labor costs. I use efficient bargaining model, which has been used extensively in the literature (Mezzetti and Dinopoulos ,1991, Bandyopadhyay and Bandyopadhyay ,2000), to inquire into the effects of union bargaining power, foreign wage, foreign and domestic subsidy and the wage in the outsourcing country.

I find that if the union is employment oriented, then an increase in its bargaining power increases domestic output and union's utility level and has an ambiguous effect on domestic profits. This result is similar to that of Mezetti and Dinopoulus (1991). I also find that if the domestic firm can credibly threaten to shift all of its production abroad, then an increase in the outsourcing country's wage may decrease union's utility and decrease domestic welfare if the union is labor oriented.

The second essay addresses the issue of illegal immigration from Mexico to the United States. According to the recent report of the INS the estimated number of illegal immigrants in the US is about 7 million, with the vast majority of those migrants being from Mexico. The INS reported that between October 1996 and January 2000, the number of illegal immigrants grew from about 5.8 million to about 7 million, an increase of more than 300,000 annually. According to the INS, the proportion of the illegal 
immigrants who are Mexican residents has increased to nearly 70 percent from less than 60 percent.

A presence of about 7 million illegal aliens in the United States clearly indicates that recent immigration policy was not effective and radical changes in immigration policy are needed to keep illegal immigration to a low level. Currently, vast majority of INS enforcement resources spent on patrolling the border and only a small fraction of those resources is directed towards interior enforcement.

Due to the lack of interior enforcement an illegal immigrant who succeeds in evading the U.S. Border Patrol on his way in, and if does not commit a crime once in the country, has little chance of ever being deported. In addition, several times since 1986 various groups of illegal immigrants have been granted a legal status. For example, the Immigration Reform and Control Act of 1986 called for an amnesty for seasonal agricultural workers that lived and worked in the country at least 90 days during 19841986. The IRCA provided legal status to about 2.7 million illegal immigrants. With this kind of incentive, many potential migrants will go long ways to evade the Border Patrol, including risking dying in the desert.

Illegal immigrants often receive help and support from their friends and relatives that recently received legal status in the country. I provide empirical evidence in support of the hypothesis, that there is a positive correlation between the number of recent legal immigrants from Mexico and the number of undocumented migrants from Mexico. This finding suggests that monitoring legal immigrants from Mexico that are likely to support undocumented residents in the United States may be a good alternative immigration 
policy for reducing illegal immigration. The finding also implies that large scale amnesties should be avoided in the future.

The third essay develops a gravity model of legal migration to the United States using balanced panel on 101 countries data for years 1996-2000. My data set includes many important countries omitted in previous migration studies, such as Ethiopia, Somalia and Nigeria in Africa; Vietnam, Iraq and Lebanon in Asia; Cuba and Haiti in the Caribbean. I include the percentage of foreign born in the US a proxy for "chain migration" effects. Despite the obvious importance of "chain migration" or "network effects" proxies for this variables are often omitted from the analysis.

As a measure of economic freedom in the source country I use the Index of Economic Freedom. Index of Freedom measures a country's economic freedom 10 broad factors of economic freedom. These factors are: trade policy, fiscal burden of government, government intervention in the economy, monetary policy, capital flows and foreign investment, banking and finance, wages and prices, property rights, regulation and black market. Higher Index of Economic Freedom for a country means that the country enjoys less economic freedom.

My results indicate that distance impairs migration flows to the United States. I also find that higher Index of Economic Freedom is associated with increased migration flows. In addition, I find that increase in migrant stock is associated with increased migration flows to the US.

The above chapters provide analyses into areas of legal and illegal immigration and outsourcing; areas that received limited attention of economists in the past. There are constantly new directions of research in these areas. My intended research agenda will 
focus on applying economic models to areas of immigration and outsourcing and providing answers to policy related questions in these areas. 


\section{REFERENCES}

Bandyopadhyay S. and Bandyopadhyay, S.C. 2000. "Efficient bargaining, welfare and strategic export policy." Journal of International trade and Economic Development 10:2, 133-149.

Bean, Frank D., Thomas J. Espenshade, Michael J. White, and Robert F. Dymowski. 1990. "Post-IRCA Changes in the Volume and Composition of Undocumented Migration to the United States: An Assessment Based on Apprehensions Data," in Frank D. Bean, Barry Edmonston, and Jeffrey S. Passel, eds., Undocumented Migration to the United States: IRCA and the Experience of the 1980's, Washington, DC: Urban Institute,1990, pp. 111-158.

Borjas, G. J. 1987. "Self-selection and the Earnings of Immigrants," American Economic Review, 77(4), pp. 531-53.

Borjas, G. J. 1989. "Economic Theory and International Migration" International Migration Review, 23(3), pp. 457-85.

Borjas, G. J. 1994. "The Economics of Immigration," Journal of Economic Literature, 32(4), pp. 1667-717.

Borjas, G. J., Bernt Bratsberg. 1996. "Who Leaves? The Outmigration of the ForeignBorn," Review of Economics and Statistics, pp. 165-176.

Brander, J.A. and Spencer B.J. 1988.’Unionized Oligopoly and International Trade Policy,” Journal of International Economics, Vol. 24, pp.217-34.

Dertouzos, J.N. and Pencavel, J.H. 1981. "Wage and employment determination under trade unionism: The international typographical union.” Journal of Political Economy $89,1162-81$.

Donato, Katherine M., Durand, Jorge and Massey, Douglas S. 1992. "Stemming the 
Tide? Accessing the Deterrent Effects of U.S. Immigration and Control.” Demography, 29(2), pp.139-57.

Espenshade, Thomas J., 1994."Does the Threat of Border Apprehension Deter Undocumented U.S. Immigration?” Population and Development Review,20(4), pp.87191.

Gastil, R. D. 1987. Freedom in the World, Greenwood Press, Westport, CT.

Greenwood M. 1975. "Research on Internal Migration in the United States: A Survey," Journal of Economic Literature, Vol. 13, No. 2. (Jun., 1975), pp. 397-433.

Greenwood M. 1985. "Human Migration:Theory, Models and Empirical Studies." Journal of regional Science, 25(4), pp.521-45.

Greenwood, M.J. 1997. “Internal migration in developed countries.” In Rosenzweig, M. and Stark,O., editors, Handbook of Population and Family Economics, Vol. 1B. NorthHolland, Amsterdam.

Hanson, Gordon H. and Antonio Spilimbergo, 1999, "Illegal Immigration, Border Enforcement, and Relative Wages: Evidence from Apprehensions at the U.S.-Mexico border." The American Economic Review, Vol. 89, 1337-1357.

Hill, John K. and James E. Pearce ( 1990), “The Incidence of Sanctions against Employers of Illegal alien's", Journal of Political Economy, Vol. 98, No. 1, 28-44. Kamemera,D.,Oguledo, V.I. and Davis, B. 2000.”A Gravity Model Analysis of International Migration to North America," Applied Economics 32(13), pp. 1745-55. MaCurdy, T.E. and Pencavel, J. 1986. "Testing between competing models of wage and employment determination in unionized markets." Journal of Political Economy 94, S3S39. 
Mayda, M.M. 2003. “A Panel Data Analysis of Economic and Non-Economic

Determinants", Working paper.

Majumdar, B. 2002. "Three Essays on Trade Policy and Factor Mobility”, WVU

Dissertation. URL: https://etd.wvu.edu/etd/etdDocumentData.jsp?jsp_etdId=2714.

Mezzetti, C. and Dinopoulos E. 1991. "Domestic unionization and import competition."

Journal of International Economics 31, 79-100.

Pencavel, J. 1984. "The tradeoff between wages and employment in trade union

objectives." Quarterly Journal of Economics 99, 215-31.

Reynolds C.W. and McCleery R.K. (1988), “The Political Economy of Immigration Law:

Impact of Simpson-Rodino on the United States and Mexico", The Journal of Economic

Perspectives, Vol 2(3), pp.117-31.

Sjaastad, L.A. 1962. "The Costs and Returns of Human Migration," The Journal of

Political Economy, Vol. 70, No.5, pp. 80-93.

Stark, O. 1991. The migration of labor. Cambridge: Blackwell, 1991.

Wadycki, W. J. 1973.'Stouflers model of migration: a comparison of interstate and metropolitan flows," Demography 12.

Ximena Clark, Timothy J. Hatton and Jeffrey Williamson. 2002.”Where do US

immigrants come from, and why?" NBER Working Paper No. 8998. 